\title{
1 Effects of pore water chemical composition on the hydro-mechanical behavior of natural stiff clays
}

4 1. Ecole des Ponts ParisTech, Navier/CERMES, Marne-la-Vallée, France (phunguyenx @ gmail.com)

5 2. Southeast University, Institute of Geotechnical Engineering, Transportation College, Nanjing, China

6 3. Euridice c/o SCK/CEN, Mol, Belgium (xli@ sckcen.be)

7 4. ONDRAF, Belgium (1.wouters@ nirond.be)

8

12 Corresponding author:

13 Prof. Yu-Jun CUI

14 Ecole des Ponts ParisTech

15 6-8 av. Blaise Pascal, Cité Descartes, Champs-sur-Marne

16 F-77455 MARNE LA VALLEE

17 France

18 Telephone: +33164153550

19 Fax: +33164153562

20 E-mail: yujun.cui@enpc.fr

21

22 
1 Abstract: Boom Clay and Ypresian Clays have been considered as potential geological host

2 formations for radioactive waste disposal in Belgium. Considering the significant differences in

3 pore water chemical composition between several sites involving these two formations as well as

4 the possible evolution of the chemical composition during the large lifespan of a radioactive

5 waste disposal, it appeared important to investigate the effects of pore water chemical

6 composition on the hydro-mechanical behaviors of these two potential host formations. In this

7 study, these effects were investigated by carrying out specific œdometer tests. Different

8 compositions were considered for this purpose: distilled water, synthetic site water, Sodium

9 Chloride solutions at concentrations of 15 and $30 \mathrm{~g} / \mathrm{L}$. Clear effects of pore water chemical

10 composition on the hydro-mechanical behavior were observed: increasing pore water salt

11 concentration gave rise to (i) increase of œdometric modulus $E_{\propto d}$, permeability $K$ and

12 consolidation coefficient $C_{v}$; and (ii) decrease of compression slope $c^{\prime}{ }_{c}$, swelling slope $c^{\prime}{ }_{s}$ and

13 secondary compression coefficient $C_{\alpha e}$, which is in agreement with the diffuse double layer

14 theory and the clay particle aggregation as identified by microstructural analyses. Furthermore,

15 the pore water chemical composition effects were found to be mineralogy, stress state and salt

16 concentration dependent: (i) Ypresian Clays with higher smectite content showed clearer

17 chemical effect on the coefficient of consolidation $C_{v}$; (ii) the chemical effects on compressibility

18 and swelling capacity parameters were found to be attenuated with increasing vertical stress; and

19 (iii) the increase of chemical effect with increasing pore water salinity was limited to a certain

20 salt concentration. The competition between the physico-chemical and mechanical effects was

21 identified: the pore water chemical composition effect is clear only in the low-stress range where

22 the hydro-mechanical behavior is dominated by the physico-chemical effect. 
1 Keywords: Boom Clay; Ypresian Clays; œdometer test; physico-chemical effect; hydro-

2 mechanical behavior.

4 1. Introduction

5 Two clay formations, Boom and Ypresian, have been considered as potential geological host

6 formations for high-level and/or long-lived radioactive waste disposal in Belgium. Several sites

7 have been investigated, such as Mol and Essen for Boom Clay, Doel and Kallo for Ypresian

8 Clays. Significant variations in pore water salinity between these sites have been reported (De

9 Craen et al., 2004, 2006; van Marcke and Laenen, 2005; van Marcke, 2009). In addition, the pore

10 water salinity at each site may also evolve at the time scale of radioactive waste disposal. This

11 can substantially affect the hydro-mechanical behavior of the host formations. Therefore, it is

12 essential to evaluate the sensitivity of the hydro-mechanical behavior of the host formations to

13 changes in pore water chemical composition.

14 Most of studies involving chemical effects on the hydro-mechanical behaviors of soils were 15 conducted on reconstituted soils and natural soft soils. Various preparation methods were

16 developed in the laboratory for this purpose: i) mixing the soil powder with a desired solution; ii)

17 immersing a soil sample in a solution; iii) percolating a soil sample by a solution. Di Maio and

18 Fenelli (1994), Di Maio (1998, 1996), Di Maio et al. (2004), Gajo and Loret (2007), Loret et al.,

19 (2002), Rao and Thyagaraj (2007), Yukselen-Aksoy et al. (2008) showed significant effects of

20 pore water saline concentration on the hydro-mechanical behavior of reconstituted expansive

21 clays with wide ranges of concentrations: i) changes in salt concentration and ion-type result in

22 reversible or irreversible volume changes of soil, mainly by osmotic consolidation or osmotic 
1 swelling; ii) increasing vertical stress reduces the extent of chemically-induced volume change;

2 and iii) the compressibility and swelling capacity are reduced by increasing salt concentration.

3 These effects have commonly been explained with the Guy-Chapman's theory of diffuse double

4 layer (Mitchell and Soga, 2005).

5 For the non-active clays, Chen et al. (2000), Olson and Mesri (1970), Sridharan and Rao (1973),

6 Wahid et al. (2011a, 2011b) found that they are relatively inert with respect to changes in pore

7 water salt concentration, but sensitive to changes in $p H$ (due to the mineral dissolution and the

8 degradation of particle edges) and dielectric constant (due to the van de Waals attractive force).

9 For the natural stiff clays, the pore water chemical composition effect has been rarely studied.

10 Swelling tests were carried out on the Callovo-Oxfordian claystone with distilled water and

11 several saline solutions under different stress levels by Daupley (1997) and Wakim (2005). It

12 was observed that the higher the salt concentration, the lower the swelling capacity. The same

13 conclusion was drawn by Coll et al. (2008) for natural Boom Clay (Mol site, $223 \mathrm{~m}$ depth). For

14 unsaturated compacted Boom Clay, Mokni et al. (2012) observed a significant effect of salt

15 concentration on the water retention property but a negligible effect on the compressibility. On

16 the other hand, only a slight pore water chemical composition effect was identified by Deng et al.

17 (2011a) on the hydro-mechanical behavior of Boom Clay at Essen (227 m depth). The reason is

18 probably the slight difference between the two solutions considered, distilled water and synthetic

19 Boom Clay water (SBCW - water prepared from salts' powder having similar chemistry as in

20 situ pore water), as well as the limited amount of smectite in Boom Clay. Comparison with

21 reconstituted expansive clays shows that natural stiff clays respond to changes in pore water salt

22 concentration in the same fashion, but to a lesser extent. This is probably due to the fact that only

23 the active clays fraction (smectite for example) in natural stiff clays is sensitive to changes in 
1 pore water chemical composition. Moreover, the natural clay structure, i.e. particle arrangement

2 and inter-particle bonding (Burland, 1990), developed at great depths since several millions years

3 may also attenuate the effect of pore water salinity changes.

4 In the present work, the effects of pore water chemical composition on the swelling capacity,

5 compressibility, permeability, consolidation and secondary compression/swelling of Boom Clay

6 and Ypresian Clays were investigated by means of specific œdometer tests. Intact samples with

7 Sodium Chloride solutions at 15 and $30 \mathrm{~g} / \mathrm{L}$-concentrations were tested. Data from two similar

8 tests on Boom Clay with distilled water and SBCW (Deng et al., 2011a; Nguyen, 2013) will be

9 incorporated for further analysis. Microstructure analyses were also performed on samples in

10 both intact and after-test states, providing further insight into the mechanisms of chemical impact

11 on the hydro-mechanical behavior of natural stiff clays.

\section{2. Materials and methods}

\section{2.1. Boom Clay}

14 Boom formation was deposited in the Rupelian stage, about 36-30 millions years ago, in the

15 Southern part of the North Sea basin (ONDRAF, 2001). In Belgium, Boom Clay is located in the

16 Northeast, in the Campine region. This Tertiary formation outcrops near the Antwerpen city,

17 gently dips and thickens toward the Northeast direction. It corresponds to a marine sediment

18 sequence of silty clays and clayey silts, and is subdivided into four members from bottom to top

19 with depths at the Essen site: Belsele-Waas (260 - 280 m), Terhagen (237 - 260 m), Putte (200 -

$20237 \mathrm{~m}$ ), and Boeretang (154 - $200 \mathrm{~m}$ ). The soil studied (BE83) was vertically cored in a borehole

21 at the Essen site, from $226.65 \mathrm{~m}$ to $227.75 \mathrm{~m}$ depth, in the lower part of Putte member. This

22 member is the most clayey one, dark gray in color, rich in organic matters and with low 
1 carbonates content (ONDRAF, 2001). Note that the underground research laboratory (URL)

2 HADES constructed at the Mol site is also situated in this member.

3 The mineralogical composition of Boom Clay BE83 (Deng et al., 2011b) was determined by X-

4 ray diffractometry and presented in Table 1 for the bulk mass and in Table 2 for the clay-size

5 fraction $(<2 \mu \mathrm{m})$. It can be observed that the Boom Clay mineralogy is dominated by non-clay

6 minerals (60\% in bulk mass), and smectite represents about $20 \%$ of the clay-size fraction.

7 The particle-size distribution curve of Boom Clay (Deng et al., 2011c) by hydrometer methods

8 following the French standard (AFNOR, 1992) is shown in Figure 1. The results of Boom Clay

9 at Mol at 223 m depth (BM223) from Baldi et al. (1988), Coll (2005), Lima (2011) and Romero

10 (1999) are also presented. It appears that Boom Clay at Mol and Essen has similar particle-size

11 distribution.

12 The physical and index properties of Boom Clay are shown in Table 3. It can be observed that

13 according to ASTM (2006), Boom Clay is highly plastic with a liquid limit $L L=67.2$ and a

14 plastic limit $P I=34.7$. Its carbonate content is quite low, and at its initial state it is fully saturated

15 with $S_{r 0} \approx 100 \%$.

16 Table 4 gives the synthetic pore water chemical composition of Boom Clay (De Craen et al.,

17 2006), indicating that $\mathrm{Na}^{+}$is the main cation.

\subsection{Ypresian Clays}

19 Ypresian Clays were formed by marine deposition during the Ypresian period (55 - $49.6 \mathrm{Ma}$ ). It

20 comprises four members, from bottom to top with depths at the Kallo site: Orchies (380 - 400

21 m), Roubaix (311 - 380 m), Aalbeke (303 - 311 m) and Kortemark (289 - 303 m). The clays

22 sequence roughly corresponds to the London clay in the Southeast of England, the basal part of 
1 the Dutch Dongen formation and the Flandres clay in Northern France (van Marcke and Laenen,

2 2005). The soil studied (YK74) was also taken from a cored borehole at the Kallo site at a depth

3 of $361.81-362.60 \mathrm{~m}$ in the lower part of the Roubaix member (Cammaer et al., 2009).

4 The mineralogical composition of Ypresian Clays YK74 by X-ray diffractometry is presented in

5 Table 1 for the bulk mass and in Table 2 for the clay-size fraction (Vandenberghe, 2011). Non-

6 clay minerals represent only $43 \%$ in the bulk mass while the smectite content is about the two-

7 third of the clay-size fraction and one-third of the bulk mass.

8 The particle-size distribution curve of Ypresian Clays is shown in Figure 1 (Vandenberghe, 9 2011). Compared to Boom Clay, Ypresian Clays are finer.

10 The physical and index properties of Ypresian Clays are shown in Table 3. According to ASTM 11 (2006), they are also highly plastic with a liquid limit $L L=136.6$, a plastic limit $P I=100.5$ and a

12 blue methylene value $V B S=13.1 \mathrm{~g} / 100 \mathrm{~g}$ (twice the value of BE83). The carbonate content is 13 low. At their initial state, Ypresian Clays are slightly unsaturated with $S_{r 0}<95 \%$.

14 The synthetic pore water chemical composition of Ypresian Clays is shown Table 4 (van 15 Marcke, 2009). $\mathrm{Na}^{+}$is also observed as the main cation with a concentration $(0.13 \mathrm{M})$ about 16 twice that of Boom Clay $(0.07 \mathrm{M})$. Note that the in situ pore water chemical compositions of 17 Boom Clay at Mol and Essen are also different (De Craen et al., 2006). Note also that the pore 18 water salinities of Ypresian Clays and Boom Clay are still respectively 4 and 7 times lower than 19 that of the North Sea (about $35 \mathrm{~g} / \mathrm{L}-0.6 \mathrm{M} \mathrm{NaCl}$ ). 
2 Oedometer tests were conducted on soil samples of $50 \mathrm{~mm}$ diameter and $20 \mathrm{~mm}$ height. These

3 samples were hand-trimmed from cores (YK74 and BE83) having the dimensions of $1.0 \mathrm{~m}$ in

4 length and $100 \mathrm{~mm}$ in diameter.

5 Figure 2 presents the test procedure adopted in this study. After installing the soil sample in the

6 œdometer cell, step loading (A-B) up to the in situ vertical effective stress $\left(\sigma_{v 0}^{\prime}=2.4\right.$ MPa for

7 BE83 and 3.2 MPa for YK74) was carried out without putting the sample in contact with water

8 in order to avoid soil swelling which would affect the soil microstructure and thereby the soil

9 hydro-mechanical behavior (Delage et al., 2007; Deng et al., 2011a, 2011b, 2011c, 2012).

10 After application of $\sigma_{v 0}^{\prime}$, the bottom porous stone and the drainage system were filled with

11 synthetic water (B-C). A controller of pressure/volume (CPV) was then used to flush synthetic

12 water out of the bottom porous stone and the drainage system via the other inlet by a desired

13 solution (distilled water, synthetic water, $\mathrm{NaCl}$ at 15 or $30 \mathrm{~g} / \mathrm{L}$-concentrations). This solution was

14 then injected through the bottom porous stone into the soil sample (C-D). The injection pressure

15 was raised in steps to $1 \mathrm{MPa}$ and then kept constant until the injected volume of the desired

16 solution was more than twice the sample pore volume. This volume criterion was expected to be

17 appropriate for fully replacing the initial pore water of the soil sample by the desired solution.

18 Based on the flow monitoring during this stage, the hydraulic conductivity and then the intrinsic

19 permeability were determined by the constant-head method. After stepwise decreasing the

20 injection pressure to zero (D-I), the CPV was replaced by a container filled with the same

21 solution in order to keep the sample saturated. 
1 Unloading from $\sigma_{v 0}^{\prime}$ to $0.05 \mathrm{MPa}$ (I-II), reloading from $0.05 \mathrm{MPa}$ to $3.2 \mathrm{MPa}$ (II-III) and

2 unloading again to $0.05 \mathrm{MPa}$ (III-IV) were finally performed in steps. The French standard

3 (AFNOR, 1997) was applied for the volume change criterion: the volume change was considered

4 as steady when the vertical strain rate was lower than $5.10^{-4} / 8 \mathrm{~h}$.

5 Table 5 summarizes the four tests $(\mathrm{BO}, \mathrm{BO} 4, \mathrm{YO} 1$ and $\mathrm{YO} 2)$ carried out in this study. Note that

6 two tests (BO1, BO2) conducted by Deng et al. (2011a) and Nguyen (2013) are also reported in

7 this table. The initial void ratio $e_{0}$ and initial degree of saturation $S_{r 0}$ for each sample are also

8 given. Scanning Electron Microscopic (SEM) and Mercury Intrusion Porosimetry (MIP) were

9 carried out on freeze-dried (Delage et al., 2006) Boom Clay samples in both the intact and after-

10 test states. These analyses were unfortunately not performed on intact Ypresian Clays sample

11 because the sample was fissured. For convenience, while analyzing the microstructure results,

12 the after-test samples are also termed by the name of the corresponding test. For instance, BO4

13 sample means the sample taken at the end of test BO4 (Boom Clay with $\mathrm{NaCl}$ solution at $30 \mathrm{~g} / \mathrm{L}$ -

14 concentration) and then freeze-dried.

\section{3. Results}

\section{3.1. Typical results and parameters definition}

17 Figure 3 presents a typical compression curve obtained from test BO4. The initial loading up to

18 the in situ vertical effective stress $\sigma_{v 0}^{\prime}=2.4 \mathrm{MPa}$ without putting soil sample in contact with

19 water resulted in a compression from $e_{0}=0.723$ to $e=0.619$ with a slope-changing point at $\sigma_{v}=$

$201.6 \mathrm{MPa}$. The degree of saturation $S_{r}$ (estimated for each step from the measured volume changes

21 assuming a constant water content $w=w_{0}$ ) reached $100 \%$ at the end of this initial loading for all

22 the tests. Le et al. (2011) also observed that Boom Clay at Mol at 223m depth (BM223) samples 
1 reached fully saturated state under a vertical stress $\sigma_{v}$ of $1.6 \mathrm{MPa}$ (indicated by the measured

2 suction equal to zero).

3 The results during soaking with $\mathrm{SBCW}$ and during injection of $\mathrm{NaCl}$ solution at $30 \mathrm{~g} / \mathrm{L}-$

4 concentration are presented in the inset diagram. It can be observed that soaking induced

5 negligible compression ( $\Delta e=0.619-0.617)$ while injection of $\mathrm{NaCl}$ at $30 \mathrm{~g} / \mathrm{L}$-concentration

6 produced a slightly higher compression $(\Delta e=0.617-0.610)$.

7 For further analysis of the chemical effect during the injection stage, volume changes during the

8 last loading step from $\sigma_{v}=1.6-2.4 \mathrm{MPa}$ before soaking, during soaking with SBCW and during

9 injection of $\mathrm{NaCl}$ solution at $30 \mathrm{~g} / \mathrm{L}$-concentration are detailed in Figure 4 . It is observed that the

10 volume change during soaking followed the same slope as the secondary compression in the last

11 loading step, indicating a continuous creep behavior without any chemical effect. During

12 injection, several mechanisms are involved: (i) unloading due to the application of injection

13 pressure $P_{C P V \max }=1 \mathrm{MPa}$; (ii) reloading due to the removal of injection pressure; (iii) creep; and

14 (iv) chemical effects due to changes in pore water chemical composition. The total compression

15 identified in Figure 3 is the combined effect of all the four mechanisms.

16 Figure 5a zooms the circled part in Figure 4. The injection pressure variation is shown in Figure

$175 \mathrm{~b}$. Considering that the maximum value of injection pressure $P_{C P V \max }=1 \mathrm{MPa}$ is much lower

18 than the in situ vertical effective stresses $\sigma_{v 0}^{\prime}=2.4$ and 3.2 MPa for Boom Clay and Ypresian

19 Clays, respectively, the unloading and reloading during the application and the removal of

20 injection pressure are rather in the elastic zone where the volume change induced can be

21 assumed to be recoverable. Thereby, the total void ratio change during this stage is related to

22 creep and chemical effects only: 


$$
\Delta \mathrm{e}_{\mathrm{inj}}=\Delta \mathrm{e}_{\mathrm{C \alpha}}+\Delta \mathrm{e}_{\mathrm{Ch}}
$$

2 with $\Delta e_{C \alpha}=-C_{\alpha e} \Delta \log t_{i n j}$. Note that $\Delta \log t_{i n j}=\log \left(t_{2} / t_{1}\right)$ is the difference in logarithm of time at

3 the end $t_{2}$ and at the beginning $t_{1}$ of the injection which are counted since the beginning of the

4 last loading up to $\sigma_{v 0}^{\prime}$ (Figure 5). The chemically-induced void ratio change $\Delta e_{C h}$ can therefore

5 be deduced from the total void ratio change $\Delta e_{i n j}$ and the creep-induced void ratio change $\Delta e_{C \alpha}$.

6 The subsequent unloading, with $\mathrm{NaCl}$ solution at $30 \mathrm{~g} / \mathrm{L}$-concentration as "new" pore water,

7 from $\sigma_{v 0}^{\prime}=2.4 \mathrm{MPa}$ (I) to $0.05 \mathrm{MPa}$ (II) gave rise to significant swell: the void ratio $e$ reached a

8 value larger than its initial one $\left(\mathrm{e}_{0}=0.723\right)$. The reloading path (II-III) formed a hysteretic loop

9 with the unloading path (I-II). The second unloading path (III-IV) was quite similar to the first

10 one (I-II).

11 From the compression curve, the compression slope $c^{\prime}{ }_{c}$ and the swelling slope $c^{\prime}{ }_{s}$ were

12 determined for each loading step. The consolidation curve of each loading step was used to

13 determine the consolidation coefficient $C_{v}$ following the Casagrande method $\left(C_{v}=0.197 H^{2} / t_{50}\right.$

14 where $H$ is the drainage length; $t_{50}$ is the time corresponding to $50 \%$ of consolidation degree), the

15 hydraulic conductivity $k\left(k=C_{v} \rho_{f} g / E_{\alpha d}\right.$; where $\rho_{f}$ is the unit mass of fluid; $g$ is the acceleration

16 due to gravity; $E_{\text {od }}$ is the œdometric modulus $)$ and intrinsic permeability $K\left(K=k \mu / \rho_{f} g\right.$ where $\mu$

17 is the fluid dynamic viscosity). The coefficient of secondary compression/swelling $C_{\alpha e}$ defined

18 as the corresponding slope $-\Delta e / \Delta \log t$ of the consolidation curve was also determined.

\subsection{Volume change during solution injection}

20 The chemically-induced volume change $\Delta \varepsilon_{v C h}$ was plotted versus the pore water $\mathrm{Na}^{+}$

21 concentration in Figure 6. It appears that for Boom Clay, injecting distilled water induced soil

22 swelling while injecting $\mathrm{NaCl}$ solution at $30 \mathrm{~g} / \mathrm{L}$-concentration induced soil compression. 
1 Moreover, the higher the pore water $\mathrm{Na}^{+}$concentration, the higher the chemically-induced

2 compression. For Ypresian Clays, injecting $\mathrm{NaCl}$ solution at $15 \mathrm{~g} / \mathrm{L}$-concentration caused soil

3 swelling while injecting $\mathrm{NaCl}$ solution at $30 \mathrm{~g} / \mathrm{L}$-concentration caused soil compression.

4 Furthermore, a linear relationship was observed between the chemically-induced volume change

5 and the pore water $\mathrm{Na}^{+}$concentration for both Boom Clay and Ypresian Clays, the two

6 relationships being parallel.

\section{3.3. Compressibility and swelling behavior}

8 Figure 7 and Figure 8 show the compression slope $c^{\prime}{ }_{c}$, swelling slope $c_{s}^{\prime}$ and œdometric modulus

$9 \quad E_{\text {œed }}$ of each loading/unloading step versus the mean vertical stress $\sigma_{v}$. As the second unloading

10 (III-IV) curve is similar to the first one (I-II), only the results of unloading I-II and reloading II-

11 III are presented in these figures.

12 For Boom Clay, a clear influence of pore water salt concentration on the compression and

13 swelling behavior was identified. The sample with distilled water (test BO1) showed the largest

$14 c^{\prime}{ }_{c}$ and $c{ }_{s}^{\prime}$ values. These values decreased in the order of samples with $\mathrm{SBCW}$ (test BO2), $\mathrm{NaCl}$

15 solution at 15 and $30 \mathrm{~g} / \mathrm{L}$-concentrations (tests $\mathrm{BO} 3$ and BO4). The highest $E_{\text {ærd }}$ was found for the

16 samples with $\mathrm{NaCl}$ solution, and followed by those for the samples with $\mathrm{SBCW}$ and distilled

17 water.

18 On the other hand, the influence of pore water salt concentration decreased as the differences

19 between the curves was reduced with increasing vertical stress $\sigma_{v}$ (from $\sigma_{v} \approx 0.5 \mathrm{MPa}$ for the

20 compression index $c^{\prime}{ }_{c}$ ). Furthermore, it is observed that the differences in $c^{\prime} c_{c}, c^{\prime}{ }_{s}$ and $E_{\propto d}$

21 between the samples with $\mathrm{NaCl}$ solution at 15 and $30 \mathrm{~g} / \mathrm{L}$-concentrations are negligible with

22 respect to those between the samples with distilled water and SBCW, and between the samples 
1 with $\mathrm{SBCW}$ and $\mathrm{NaCl}$ solution at $15 \mathrm{~g} / \mathrm{L}$-concentration. For Ypresian Clays, only the $\mathrm{NaCl}$

2 solution at 15 and $30 \mathrm{~g} / \mathrm{L}$-concentrations were considered, and the differences in $c^{\prime}{ }_{c}, c^{\prime}{ }_{s}$ and $E_{\text {od }}$

3 between the two corresponding samples were not clear.

4 The consolidation coefficient $C_{v}$ for each loading step during reloading path II-III is shown in

5 Figure 9 versus the mean void ratio $e$ and the mean vertical stress $\sigma_{v}$. It is observed that $C_{v}$

6 decreased with compression (increasing $\sigma_{v}$, decreasing $e$ ) and then increased again. A clear

7 chemical effect was observed for both soils as $C_{v}$ increased with increasing pore water $\mathrm{Na}^{+}$

8 concentration. At a given void ratio or vertical stress, the difference in $C_{v}$ between Ypresian

9 Clays samples with $\mathrm{NaCl}$ solution at 15 and $30 \mathrm{~g} / \mathrm{L}-$ concentrations is higher than for Boom Clays

10 samples.

11 The variations of the coefficient of secondary compression/swelling $C_{\alpha e}$ with void ratio $e$ at the

12 end of each step is shown in Figure 10. As $C_{\alpha e}=-\Delta e / \Delta \log t$, it is positive during loading and

13 negative during unloading. A clear pore water chemical effect was observed for Boom Clay upon

14 reloading (II-III): the higher the salt concentration, the lower the value of $C_{\alpha e}$ at a given void

15 ratio. Moreover, the chemical effect was negligible at (i) low void ratio $e$ (high vertical stress $\sigma_{v}$ )

16 and increased with increasing $e$ (decreasing $\sigma_{v}$ ); (ii) high concentration and increased with

17 decreasing concentration. However, the chemical effect on $C_{\alpha e}$ upon unloading was not clear.

18 The correlations between the coefficient of secondary compression $C_{\alpha e}$ and compression slope

$19 c_{c}^{\prime}$ and between the coefficient of secondary swelling $C_{\alpha e}$ and swelling slope $c^{\prime}{ }_{s}$ are shown in

20 Figure 11. A linear relationship between $C_{\alpha e}$ and $c^{\prime}{ }_{c}$ was attempted: $C_{\alpha e} / c^{\prime}{ }_{c}=0.024$ for Boom

21 Clay and 0.015 for Ypresian Clays, while a bi-linear relationship between $C_{\alpha e}$ and $c$ 's was

22 verified. The chemical effect on these correlations was not clear. 
2 The intrinsic permeability $K$ measured at the end of injection phase by the constant-head method 3 and that determined by back-analysis using the consolidation curve of each reloading step (phase

4 II-III) are shown in Figure 12 in a logarithmic scale as function of void ratio $e$. Linear 5 relationships were obtained in this semi-logarithmical plane for Boom Clay and Ypresian Clays.

6 Moreover, these relationships are parallel for each clay. Noticeable chemical effect was

7 identified for both soils: the sample with higher pore water $\mathrm{Na}^{+}$concentration showed higher $K$,

8 even though the difference between Boom Clay samples with distilled water and SBCW was not 9 clear.

\subsection{Microstructure observation}

11 Figure 13 and Figure 14 show the MIP results for Boom Clay and Ypresian Clays, respectively.

12 The intruded mercury void ratio $e_{m}$ is defined as the ratio of mercury intrusion volume $V_{m}$ to soil

13 solid volume $V_{s}$. Note that the MIP technique can only cover a limited range of pore size, from

14300 to $0.005 \mu \mathrm{m}$ in apparent mercury entrance diameter D (corresponding to a pressure range

15 from 0.1 to $200 \mathrm{MPa})$.

16 Intact Boom Clay showed mono-modal pore-size distribution (Figure 13b) with a dominant pore

17 size around $D=0.15 \mu \mathrm{m}$ - meso-pore following Romero (1999). After "replacing" the in situ

18 pore water by $\mathrm{NaCl}$ solution at 15 (test $\mathrm{BO} 3$ ) or $30 \mathrm{~g} / \mathrm{L}$-concentrations (test $\mathrm{BO} 4$ ) and applying

19 an unloading-reloading-unloading path under low vertical stresses $\left(0.05 \leq \sigma_{v} \leq 3.2 \mathrm{MPa}\right)$, the

20 pore size distributions became more or less bi-modal with creation of a population of micro-pore

21 around $D=0.06 \mu \mathrm{m}$, the population of meso-pore being at $D=0.25 \mu \mathrm{m}$ that was slightly larger

22 than the initial one. It appears also that under chemical and mechanical loadings (i) the pores 
1 smaller than $D=0.06 \mu \mathrm{m}$ were not affected; (ii) the density of intermediate pores $(0.06 \leq D \leq$

$20.2 \mu \mathrm{m})$ was reduced and (iii) the density of larger pores $(D \geq 0.3 \mu \mathrm{m})$ was increased. It is also

3 observed that the density of the meso-pore population of $\mathrm{BO} 4$ sample (with $\mathrm{NaCl}$ solution at 30

$4 \mathrm{~g} / \mathrm{L}-$ concentration) is higher than that of $\mathrm{BO} 3$ (with $\mathrm{NaCl}$ solution at $15 \mathrm{~g} / \mathrm{L}$-concentration). Note

5 that the populations appeared around $D=100 \mu \mathrm{m}$ may correspond to macro-fissures created

6 during sample preparation.

$7 \mathrm{YO} 1$ and $\mathrm{YO} 2$ samples with $\mathrm{NaCl}$ solution at 15 and $30 \mathrm{~g} / \mathrm{L}$-concentrations, respectively, show

8 dominant micro-pores of $0.10 \mu \mathrm{m}$ diameter. This dominant pore size is significantly smaller than

9 that of the meso-pore populations of $\mathrm{BO} 3$ and $\mathrm{BO} 4$ samples.

10 Figure 15 and Figure 16 show the SEM photos for Boom Clay and Ypresian Clays, respectively,

11 on the section perpendicular to the bedding plane marked by black lines. On the left side are the

12 photos in dimensions of $125 \times 100 \mu \mathrm{m}$, except for YO2 with dimensions of $250 \times 200 \mu \mathrm{m}$. These

13 figures were then zoomed to reach dimensions of $25 \times 20 \mu \mathrm{m}$, except for $\mathrm{YO} 2$ with dimensions of

$1462.5 \times 50 \mu \mathrm{m}$, on the right side. Well-developed preferential alignments of clay particles in the

15 direction parallel to the bedding plane for both Boom Clay and Ypresian Clays were observed.

16 Comparing SEM photos of intact and BO3-4 samples shows that more clay aggregates were

17 formed with a diameter around $10 \mu \mathrm{m}$ in BO3-4 sample. Clay particles seemed to be thicker as a

18 result of more stacked-up clay layers, and large inter-particle pores and small intra-particle ones

19 were formed. Boom Clay after test became less dispersed as compared with its initial

20 microstructure. Some connected pores of $1 \mu \mathrm{m}$ diameter in Boom Clay (Figure 15c, d, e, f) and

$21 \quad 2-5 \mu \mathrm{m}$ in Ypresian Clays (Figure 16) were identified. 


\section{Discussion}

3 During the injection phase, the chemically-induced swelling by distilled water (test BO1),

4 compressions by $\mathrm{NaCl}$ solutions at 15 (test BO3) and $30 \mathrm{~g} / \mathrm{L}$-concentrations (test $\mathrm{BO} 4$ ) for Boom

5 Clay, and also compression by $\mathrm{NaCl}$ solution at $30 \mathrm{~g} / \mathrm{L}$-concentration (test $\mathrm{YO} 2$ ) for Ypresian

6 Clays are in agreement with the common observations in terms of pore water salt concentration

7 effects on the volume change behavior of active clays (Castellanos et al., 2008; Di Maio, 1996;

8 Musso et al., 2013). These volume changes can be considered as osmotic swelling/consolidation

9 as described by the diffuse double layer theory (Chapman, 1913; Gouy, 1910) or as osmotic

10 suction changes $\Delta \pi$ : as the salt concentration increases, the double layer thickness decreases and

11 the osmotic suction $\pi$ increases, leading to shrinkage of clay particles and hence volume change

12 in the macroscopic level. However, the chemically-induced swells observed on Boom Clay

13 sample with SBCW and Ypresian Clays sample with $\mathrm{NaCl}$ solution at $15 \mathrm{~g} / \mathrm{L}$-concentration

14 suggest that other mechanisms are involved in this "chemically-induced" volume change. Further

15 studies are then needed to clarify this point.

\subsection{Compressibility and swelling capacity}

17 In general, the hydro-mechanical behavior of clays is governed by the competing physico18 chemical and mechanical effects (Cui et al., 2002, Le et al., 2011). The term "mechanical" refers

19 to particles interactions through their direct contacts, while the term "physico-chemical" denotes

20 interactions through the diffuse double layer (Robinson and Allam, 1998). Thus, for each loading

21 or unloading path, there is a threshold stress $\sigma_{s}$ dividing the compression curve into two zones,

22 each one being governed by one effect (Figure 17): (i) upon unloading, when the external stress 
1 is higher than the repulsive force related to the soil particles-water interaction (physico-chemical

2 effect) or $\sigma_{v}>\sigma_{s l}$ for I-II path or $\sigma_{s 3}$ for III-IV path, low swelling volume change occurs;

3 otherwise ( $\sigma_{v}<\sigma_{s l}$ or $\sigma_{s 3}$ ), higher swelling volume change can be expected; (ii) upon reloading,

4 when the external stress is lower than the matric suction related to the physico-chemical effect

$5 \quad\left(\sigma_{v}<\sigma_{s 2}\right)$, this external stress is balanced by the repulsive force, leading to a small volume

6 decrease; on the contrary, when the external stress becomes higher $\left(\sigma_{v}>\sigma_{s 2}\right)$, the mechanical

7 effect becomes dominant giving rise to larger volume decrease (Cui et al., 2013; Nguyen, 2013).

8 For Boom Clay and Ypresian Clays, the values of threshold stress $\sigma_{s}$ are practically similar,

9 estimated at about $\sigma_{s 1} \approx \sigma_{s 3} \approx 1.5 \mathrm{MPa}$ upon unloading and $\sigma_{s 2} \approx 0.5 \mathrm{MPa}$ upon reloading

10 (Nguyen, 2013). .

11 Deng et al. (2012) investigated the secondary compression behavior of Boom Clay and also

12 observed a linear relationship between $C_{\alpha e}$ and $c_{c}^{\prime}$, and a bi-linear relationship between $C_{\alpha e}$ and

$13 c^{\prime} s$. These authors also related this bi-linearity to the competition between two mechanisms:

14 mechanically dominated rebounding and physico-chemically dominated swelling. The linearity

15 during reloading was however explained by the mechanical effect that is supposed to be the only

16 governing mechanism. If we admit the previous interpretations, a bi-linearity between $C_{\alpha e}$ and

$17 c^{\prime}{ }_{c}$ should also be obtained, instead of linearity. The linear relationship between $C_{\alpha e}$ and $c^{\prime} c$

18 obtained during the reloading path in Deng et al. (2012) and in this study could be explained by

19 lack of some $C_{\alpha e}$ values corresponding to the first reloading steps under $\sigma_{v}<\sigma_{s 2} \approx 0.5 \mathrm{MPa}$

20 where hydro-mechanical behavior is expected to be governed by the physico-chemical effect.

21 Robinson and Allam (1998) discussed the mechanical and physico-chemical effects on the

22 consolidation coefficient $C_{v}$, and concluded that the increase of $C_{v}$ with increasing $\sigma_{v}$ is due to 
1 the dominance of mechanical effect while the decrease of $C_{v}$ is related to the increasing physico-

2 chemical effect. This is consistent with the variations of $C_{v}$ shown in Figure 9. On the other

3 hand, it has been commonly observed that (i) $C_{v}$ decreases with increasing liquid limit $L L$

4 (Carrier, 1985; Raju et al., 1995; Robinson and Allam, 1998; Sridharan and Nagaraj, 2004); and

5 (ii) $L L$ increases with decreasing salt concentration (Di Maio, 1996; Gajo and Maines, 2007).

6 This is also consistent with the results obtained in this study: the higher the pore water salt

7 concentration, the higher the consolidation coefficient $C_{v}$.

8 It was observed in this study that the higher the pore water salt concentration, the higher the

9 values of œdometer modulus $E_{\text {} d ~}$ and coefficient of consolidation $C_{v}$, the lower the values of

10 compression/swelling slope $c^{\prime} d c^{\prime}{ }_{s}$ and secondary compression coefficient $C_{\alpha e}$. This chemical

11 effect was attenuated with increasing vertical stress $\sigma_{v}$. This is in agreement with the previous

12 results on both natural clays (Deng et al., 2011a; Wakim, 2005) and reconstituted swelling clays

13 (Di Maio and Fenelli, 1994; Di Maio, 1996; Di Maio et al., 2004; Rao and Thyagaraj, 2007).

14 Basically, the pore water chemical composition effect should be more pronounced in the stress

15 range where physico-chemical effects dominate. Indeed, when considering the chemical effects

16 on soil compressibility and swelling capacity upon unloading (I-II and III-IV), it is observed that

17 the variations of these parameters with different "new" pore waters are similar (the curves are

18 parallel) until the threshold stress $\sigma_{s l} \approx 1.5 \mathrm{MPa}$ (Figure 17). Below the values of threshold stress

$19 \sigma_{s}$, the curves start to have different slopes, increasing thereby the difference between the

20 parameters with different "new" pore waters. Upon reloading (II-III), when the vertical stress

21 was still below the threshold stress $\sigma_{v}<\sigma_{s 2} \approx 0.5 \mathrm{MPa}$, the difference between the parameters

22 with different "new" pore waters are large while beyond the threshold $\sigma_{s}$, the gap is reduced with

23 the curves approaching each other and become parallel again. This illustrates again that the pore 
1 water chemical composition effects exhibit mainly in the stress range where the hydro-

2 mechanical behaviour is dominated by physico-chemical effects.

3 It was found on Boom Clay that the increase of chemical effect with increasing pore water

4 salinity was limited to a certain salt concentration. This observation was also reported in Di Maio

5 et al. (2004) for several reconstituted clays of different smectite contents. Di Maio et al. (2004)

6 also observed that the stabilizing concentration for a more expansive soil is lower. Thereby, the

7 chemical effects on Ypresian Clays (containing higher smectite) should be stabilized at a lower

8 pore water salt concentration than on Boom Clay. This is confirmed by that fact that the

9 differences in $E_{\alpha d}, c_{c}^{\prime}, c_{s}^{\prime}$, and $C_{\alpha e}$ of Ypresian Clays between $\mathrm{NaCl}$ solution at 15 and $30 \mathrm{~g} / \mathrm{L}$ -

10 concentrations were found to be negligible.

\section{4.3. Permeability}

12 In the phase of in situ pore water replacement, it was observed that the higher the salt solution

13 concentration, the higher the soil compression, and also the higher intrinsic permeability.

14 Because, in general, permeability decreases with decrease of void ratio, the increased

15 permeability must be due to other factors involved in this process.

16 Fernandez and Quigley (1985), Cui et al. (2003), while respectively studying a natural clay and

17 the compacted Jossigny silt with distilled water and non-polar fluids, observed the importance of

18 percolating fluid dielectric constant $D$ : significant aggregation was observed with lower fluid

19 dielectric constant, that led to a drastic increase in permeability. This is consistent with the

20 results obtained in the present study because according to Wang and Anderko (2001), the

21 dielectric constant $D$ decreases in the order of distilled water, $\mathrm{SBCW}, \mathrm{NaCl}$ solution at 15 and 30

$22 \mathrm{~g} / \mathrm{L}$-concentrations, and this is also the increasing order of measured permeability. 
1 On the other hand, previous works on FEBEX bentonite (Castellanos et al., 2008), MX-80

2 bentonite (Karnland et al., 1992; Villar, 2005), Na-Montmorillonite-sand mixtures (Studds et al.,

3 1998), compacted Montmorillonite and Illite (Rolfe and Aylmore, 1977) and Friedland Ton clay

4 - a natural clay with $45 \%$ smectite (Push, 2001) also evidenced a clear increase in hydraulic

5 conductivity with the increasing saline concentration of permeating fluid. Following Castellanos

6 et al. (2008), several mechanisms can be involved, such as (i) modification of pore size

7 distribution resulting from clay matrix swelling, and (ii) variations of water molecule mobility

8 associated with exchangeable cations adsorbed on the clay sheet surfaces or in the diffuse double

9 layer. Consequently, when the pore water salt concentration increases, there is reduction in the

10 swelling capacity of clay particles, thus increasing large flow channel (inter-aggregate) size,

11 causing permeability increase. On the contrary, any decrease in pore water salt concentration

12 produces higher development of diffuse edouble layer, causing a decrease in permeability as a

13 result of the decrease of the size of large flow channels.

14 The explanations above lead to the same conclusion in terms of microstructure changes: the size

15 of large pores is increased by clay aggregation due to the pore water salt concentration increase,

16 and the soil permeability is increased. After percolation, the influence of pore water salt

17 concentration on permeability remained the same upon unloading-reloading-unloading: the

18 higher the salt concentration, the higher the permeability. Moreover, the same slope of $e-\log K$

19 curves was observed for each soil with different pore water chemical compositions, suggesting

20 that the chemical effect on permeability was not affected by the vertical stress within the range

21 considered. This means that the microstructure changes upon percolation can be considered as

22 preserved during the unloading-reloading-unloading paths (I-II-III-IV). In other words, clay

23 aggregation due to percolating $\mathrm{NaCl}$ solution at 15 and $30 \mathrm{~g} / \mathrm{L}$-concentrations (higher than the in 
1 situ pore water salinity) was preserved until the end of the tests. The microstructure analyses by

2 MIP and SEM confirmed this conclusion (see Figures 13-16).

\section{5. Conclusions}

4 The pore water salt concentration effects on the behaviors of natural Boom Clay and Ypresian

5 Clays were investigated in terms of volume change, compressibility, swelling capacity, 6 consolidation, creep and permeability. The results allow the following conclusions to be drawn:

7 (1) Percolation of a higher salt concentration solution induced soil compression (osmotic 8 consolidation) while percolation of distilled water resulted in soil swelling (osmotic 9 swelling); this is in agreement with the diffuse double layer theory;

10 (2) The higher the pore water salt concentration, the higher the odometric modulus $E_{\propto d}$ and 11 the coefficient of consolidation $C_{v}$, the lower the compression/swelling slope $c^{\prime}{ }_{c} / c^{\prime}{ }_{s}$ and 12 the secondary compression coefficient $C_{\alpha e}$; this is also in agreement with the diffuse 13 double layer theory;

14 (3) A higher chemical effect on the coefficient of consolidation $\mathrm{C}_{\mathrm{v}}$ was identified for 15 Ypresian Clays that have a higher smectite content than Boom Clay;

16 (4) The higher the pore water salt concentration, the higher the intrinsic permeability $K$ due 17 to the microstructure changes by clay aggregation - larger flow channels are formed as 18 observed in the MIP and SEM analyses;

19 (5) The chemical effect on permeability was observed to be independent of vertical stress as 20 the chemically-induced microstructure changes were preserved under mechanical 21 loading; 

14 radioactive waste disposal, can go further by: without doing separated swelling tests;

(6) The pore water chemical composition effects on the compressibility and swelling capacity parameters were attenuated with increasing vertical stress $\sigma_{v}$ upon loading/ unloading; bi-linear relationships between $C_{\alpha e}$ and $c^{\prime}{ }_{s}$ were identified for Boom and Ypresian Clays; $C_{v}$ showed a decrease followed by an increase with increasing $\sigma_{v}$ for both soils. This evidenced the competition between the physico-chemical effect and the mechanical effect as identified by Cui et al. (2013) and Nguyen (2013). This also showed that the pore water salt concentration effect prevails only in the region where the hydromechanical behavior is dominated by the physico-chemical effect;

(7) The variations of compressibility and swelling capacity parameters showed that the chemical effects stabilized at a certain concentration, and this limit concentration seemed to decrease with increasing active clay minerals like the smectite.

Future characterizations on the pore-water chemical composition effects on the hydromechanical behaviours of natural stiff clays, Belgian candidate for host formation of geological

(i) applying a more severe criterion of pore-water replacement, for example, by collecting and measuring electrical conductivity of the expulsed water at the outlet upon injection phase, instead of a simple volumic criterion at the inlet as in the present study;

(ii) applying a better load path with smaller loading/unloading steps around the swelling (threshold) stress $\sigma_{s}$, so that chemical effect on the swelling stress could be investigated

(iii) testing Ypresian Clays with distilled water and lower salt concentrations, as for Boom Clay in the present study, to fully investigate chemical effect on this formation. On the 
other side, higher salt concentrations (> $30 \mathrm{~g} / \mathrm{L}$ ) should tested as well on both formations to confirm the stabilizing concentration of chemical effects on the hydro-mechanical behaviours, and thus give a more complete information to the end-users on the variation ranges of the hydro-mechanical parameters under these effects for short- and long-term safety assessements.

\section{References}

AFNOR, 1992. Sols: reconnaissance et essai. Analyse granulométrique des sols. Méthode par sédimentation.

AFNOR, 1997. Sols: reconnaissance et essais. Essais œdométriques. Partie 1: Essai de compressibilité sur matériaux fins quasi saturés avec chargement par paliers.

ASTM, 2006. Standard Practice for Classification of Soils for Engineering Purposes (Unified Soil Classification System) D 2487 - 06.

Baldi, G., Hueckel, T., Pellegrini, R., 1988. Thermal volume changes of the mineral-water system in low-porosity clay soils. Canadian geotechnical journal 25, 807-825.

Burland, J.B., 1990. On the compressibiity and shear strength of natural clays. Géotechnique 40, 329-378.

Cammaer, C., Cockaerts, G., Schiltz, M., 2009. Drilling and géological report ON-KALLO-1, ON-KALLO-2, ON-KALLO-3 ( No. Samsuffit R2009-01). ONDRAF/NIRAS.

Carrier, W.D., 1985. Consolidation Parameters Derived From Index Tests. Geotechnique 35, 211-213.

Castellanos, E., Villar, M.V., Romero, E., Lloret, A., Gens, A., 2008. Chemical impact on the hydro-mechanical behaviour of high-density FEBEX bentonite. Physics and Chemistry of the Earth 33, S516-S526.

Chapman, D.L., 1913. A contribution to the theory of electrocapillarity. Philosophical Magazine $25,475-481$.

Chen, J., Anandarajah, A., Inyang, H., 2000. Pore fluid properties and compressibility of kaolinite. Journal of geotechnical and geoenvironmental engineering 126, 798-807.

Coll, C., 2005. Endommagement des roches argileuses et perméabilité induite au voisinage d'ouvrage souterrains. Université Joseph Fourier-Grenoble 1, Grenoble.

Coll, C., Collin, F., Radu, J.P., Illing, P., Schroeder, C., Charlier, R., 2008. Longterm behavior of Boom Clay. Influence of clay viscosity on the far field pore pressure distribution. ULg. 
Cui, Y.J., Yahia-Aissa, M. and Delage, P., 2002. A model for the volume change behaviour of heavily compacted swelling clays. Engineering Geology 64 (2-3), 233-250. Cui, Y.J., Delage, P., Alzoghbi, P., 2003. Retention and transport of a hydrocarbon in a silt. 4 Géotechnique 53, 83-91.

Cui, Y.J., Nguyen, X.P., Tang, A.M., Li, X.L., 2013. An insight into the unloading/reloading loops on the compression curve of saturated clays. Applied Clay Science. Accepted for publication.

8 Daupley, X., 1997. Etude du potentiel de l'eau interstitielle d'une roche argileuse et de relations 9 entre ses propriétés hydriques et mécaniques. Application aux argilites de Torcien de la région de Tournemire. Ecole Nationale Supérieure des Mines de Paris, Géologie de l'Ingénieur.

De Craen, M., Wang, L., van Geet, M., Moors, H., 2004. Geochemistry of Boom Clay pore water at the Mol site - Status 2004 (Scientific report No. SCK•CEN-BLG-990-04/MDC/P-48).

13 SCK•CEN, Waste \& Disposal Department, Boeretang 200, 2400 Mol, Belgium.

14 De Craen, M., Wemaere, I., Labat, S., van Geet, M., 2006. Geochemical analyses of Boom Clay pore water and underlying aquifers in the Essen-1 borehole ( No. SCK •CEN-ER-19. 06/MDC/P47). SCK $\cdot$ CEN.

17 Delage, P., Marcial, D., Cui, Y.J., Ruiz, X. (2006). Ageing effects in a compacted bentonite: A 18 microstructure approach, Géotechnique 56 (5), 291-304.

Delage, P., Le, T. T., Tang, A. M., Cui, Y. J. \& Li, X. L. (2007), 'Suction effects in deep boom clay block samples', Géotechnique 57 (1), 239-244.

Deng, Y.F., Cui, Y.J., Tang, A.M., Nguyen, X.P., Li, X.L., van Geet, M., 2011a. Investigating the pore-water chemistry effects on the volume change behaviour of Boom clay. Physics and 23 Chemistry of the Earth 36, 1905 - 1912.

24 Deng, Y.F., Tang, A.M., Cui, Y.J., Nguyen, X.P., Li, X.L., Wouters, L., 2011b. Laboratory hydro-mechanical characterisation of Boom Clay at Essen and Mol. Physics and Chemistry of the Earth 36, 1878 - 1890.

Deng, Y.F., Tang, A.M., Cui, Y.J., Li, X.L., 2011c. Study on the hydraulic conductivity of Boom clay. Canadian Geotechnical Journal 48, 1491-1470.

Deng, Y.F., Cui, Y.J., Tang, A.M., Li, X.L., Sillen, X., 2012. An experimental study on the secondary deformation of Boom Clay. Applied Clay Science 59-60, 19-25.

Di Maio, C., 1996. Exposure of bentonite to salt solution: osmotic and mechanical effects. Géotechnique 46, 695-707.

33 Di Maio, C., 1998. Discussion: Exposure of bentonite to salt solution: osmotic and mechanical 34 effects. Di Maio, C., 1996. Géotechnique 46 (4), 695-707. Géotechnique 48, 433-436.

Di Maio, C., Fenelli, G.B., 1994. Residual strength of kaolin and bentonite: the influence of their constituent pore fluid. Géotechnique 44, 211-226.

37 Di Maio, C., Santoli, L., Schiavone, P., 2004. Volume change behavior of clays: the influence of 38 mineral composition, pore fluid composition and stress state. Mechanics of Materials 36, 43539451.

40 Fernandez, F., Quigley, R.M., 1985. Hydraulic conductivity of natural clays permeated with 
simple liquid hydrocarbons. Canadian Geotechnical Journal 22, 205-214.

Gajo, A., Loret, B., 2007. The mechanics of active clays circulated by salts, acids and bases. Journal of the Mechanics and Physics of Solids 55, 1762-1801.

Gajo, A., Maines, M., 2007. Mechanical effects of aqueous solutions of inorganic acids and bases on a natural active clay. Géotechnique 57, 687-699.

Gouy, G., 1910. Sur la constitution de la charge electrique a la surface d'un electrolyte. Anniue Physique (Paris) 9, 457-468.

Karnland, O., Pusch, R., Sandén, T., 1992. The importance of electrolyte on the physical properties of MX-80 bentonite ( No. Report AR 92-35). SKB, Stockholm (in Swedish).

Le, T.T., Cui, Y.J., Munoz, J.J., Delage, P., Tang, A.M., Li, X.L., 2011. Studying the stresssuction coupling in soils using an odometer equipped with a high capacity tensiometer. Front. Archit. Civ. Eng.China, 5(2), 160-170.

13 Lima, A., 2011. Themo-Hydro-Mechanical behaviour of two deep Belgian clay formations: 14 Boom and Ypresian clays. Universitat Politècnica de Catalunya, Spain.

Loret, B., Hueckel, T., Gajo, A., 2002. Chemo-mechanical coupling in saturated porous media: elastic-plastic behaviour of homoionic expansive clays. International Journal of Solids and 17 Structures 39, 2773-2806.

18 Mitchell, J.K., Soga, K., 2005. Fundamentals of soil behavior. John Wiley \& Sons, Inc.

Mokni, N., Romero, E., Olivella, S., 2012. Joint effect of osmotic and matric suction on hydromechanical behavior of Boom Clay. Presented at the Clay in natural and engineered barriers for radioactif waste confinement. 5th international meeting, Montpellier.

Musso, G., Romero, E., Vecchia, G.D., 2013. Double-structure effects on the chemo-hydromechanical behaviour of a compacted active clay. Géotechnique 63, 206-220.

Nguyen, X.P., 2013. Étude du comportement chimico-hydro-mécanique des argiles raides dans le contexte du stockage géologique de déchets radioactifs. Ecole des Ponts ParisTech.

Olson, R.O., Mesri, G., 1970. Mechanisms controlling compressibility of clays. Journal of Soil Mechanics and Foundation Division, Proceeding of the American Society of Civil Engineers 6, $1863-1878$.

ONDRAF, 2001. Safety Assessment and Feasibility Interim Report 2 ( No. SAFIR2). ONDRAF.

Push, R., 2001. Experimental study of the effect of high porewater salinity on the physical properties of a natural smectitic clay ( No. Technical Report TR-01-07). SKB, Stockholm.

Raju, N.P.S.R., Pandian, N.S., Nagaraj, T.S., 1995. Analysis and Estimation of Coefficient of Consolidation. Geotechnical Testing Jounal 18, 252-258.

34 Rao, S.M., Thyagaraj, T., 2007. Swell-compression behavior of compacted clays under chemical 35 gradients. Canadian Geotechnical Journal 44, 520-532.

36 Robinson, R.G., Allam, M.M., 1998. Effect of clay mineralogy on coefficient of consolidation. 37 Clays and Clay Minerals 46, 596-600.

38 Rolfe, P.F., Aylmore, L.A.G., 1977. Water and salt flow through compacted clays: I. 39 Permeability of compacted illite and montmorillonite. Soil Science Society of America Journal 
$141,489-495$.

2 Romero, M.E., 1999. Characterisation and thermo-hydro-mechanical behaviour of unsaturated 3 Boom clay: an experimental study. Universitat Politècnica de Catalunya.

4 Sridharan, A., Nagaraj, B., 2004. Coefficient of Consolidation and its Correlation with Index 5 Properties of Remolded Soils. Geotechnical Testing Jounal 27, 1-6.

6 Sridharan, A., Rao, G.V., 1973. Mechanisms controlling volume change of saturated clays and 7 the role of the effective stress concept. Géotechnique 23, 359-382.

8 Studds, P.G., Stewart, D.I., Cousens, T.W., 1998. The effects of salt solutions on the properties 9 of bentonite-sand mixtures. Clay Minerals 33, 651-660.

10 van Marcke, P., 2009. Existing information on the Ypresian clays, in: Meeting on the THMC 11 Characterisation of Ypresian Clays.

12 van Marcke, P., Laenen, B., 2005. The Ypresian clay as possible host rock for radioactive waste 13 disposal: An evaluation. ONDRAF.

14 Vandenberghe, N. (2011), Qualitative \& quantitative mineralogical analyses of ypresian clay, 15 Technical report, KU Leuven.

16 Villar, M.V., 2005. MX-80 bentonite. Thermo-hydro-mechanical characterisation performed at 17 CIEMAT in the context of the prototype project. ( No. Informes Técnicos 1053). CIEMAT, 18 Madrid.

19 Wahid, A.S., Gajo, A., Di Maggio, R., 2011a. Chemo-mechanical effects in kaolinite. Part 1: 20 prepared samples. Géotechnique 61, 439-447.

21 Wahid, A.S., Gajo, A., Di Maggio, R., 2011b. Chemo-mechanical effects in kaolinite. Part 2: 22 exposed samples and chemical and phase analyses. Géotechnique 61, 449-457.

23 Wakim, J., 2005. Influence des solutions aqueuses sur le comportement mécanique des roches 24 argileuses. Ecole Nationale Supérieure des Mines de Paris.

25 Wang, P., Anderko, A., 2001. Computation of dielectric constants of solvent mixtures and 26 electrolyte solution. Fluid phase equilibria 186, 203-122.

27 Yukselen-Aksoy, Y., Kaya, A., Ören, A. H., 2008. Seawater effect on consistency limits and 28 compressibility characteristics of clays. Engineering Geology 102, 54-61. 
2 Table 1: Mineralogical compositions in Boom (BE83) and Ypresian (YK74) Clays

3 Table 2: Mineralogical composition in the clay fractions (fraction $<2 \mu \mathrm{m}$ )

4 Table 3: Physical and index properties of Boom and Ypresian Clays

5 Table 4: Pore-water chemical compositions for Boom and Ypresian Clays

6 Table 5: Test program

$7 \quad$ List of Figures

8 Figure 1: Particle-size distribution curves of Boom and Ypresian Clays

9 Figure 2: Typical loading procedure

10 Figure 3: Compression curve of test $\mathrm{BO} 4$ (Boom Clay, $\mathrm{NaCl}$ solution at $30 \mathrm{~g} / \mathrm{L}$-concentration)

11 Figure 4: Consolidation curve for the last loading step before soaking, soaking and injection of $12 \mathrm{NaCl}$ solution at $30 \mathrm{~g} / \mathrm{L}$-concentration in test BO4 (Boom Clay)

13 Figure 5: Void ratio (a) and injection pressure (b) changes during the injection phase in test BO4 14 (Boom Clay, $\mathrm{NaCl}$ solution at $30 \mathrm{~g} / \mathrm{L}$-concentration)

15 Figure 6: Chemically induced volume change versus pore water $\mathrm{Na}^{+}$concentration during 16 solution injection

17 Figure 7: Variations of swelling (a) and compression (b) slopes with vertical stress

18 Figure 8: Variations of œdometric modulus with vertical stress during unloading I-II (a) and 19 reloading II-III (b)

20 Figure 9: Variations of consolidation coefficient with a) void ratio and b) vertical stress during 21 reloading

22 Figure 10: Variations of secondary compression/swelling coefficient with void ratio for Boom 23 Clay and Ypresian Clays

24 Figure 11: Correlations between $C_{\alpha e}$ and $c{ }_{c}$ or $c{ }_{s}$ for Boom Clay and Ypresian Clays

25 Figure 12: Variations of intrinsic permeability with void ratio

26 Figure 13: Results of MIP tests on Boom Clay: (a) cumulative curves, (b) derived curves

27 Figure 14: Results of MIP tests on Ypresian Clays: (a) cumulative curves, (b) derived curves

28 Figure 15: SEM photos of Boom Clay samples on the section perpendicular to bedding plane 29 (marked by black lines)

30 Figure 16: SEM images of Ypresian Clays samples on the section perpendicular to the bedding 31 plane (marked by black lines)

32 Figure 17: Threshold stress $\sigma_{s}$ 
Table 1: Mineralogical compositions in Boom (BE83) and Ypresian (YK74) Clays

\begin{tabular}{lcc} 
Minerals (wt \%) & BE83 $^{(1)}$ & YK74 $^{(2)}$ \\
\hline Clays & 40 & 57 \\
Illite & 10 & 5 \\
Kaolinite & 30 & 3 \\
Smectite & & 33 \\
Illite/Smectite & & 12 \\
Chlorite (or others) & & 4 \\
\hline Non clays & 60 & 43 \\
Quartz & 60 & 31 \\
Dolomite & & 0.8 \\
Pyrite & Trace & 0.4 \\
K-feldspar & Trace & 6 \\
Plagioclase & & 5 \\
\hline
\end{tabular}

2

Table 2: Mineralogical composition in the clay fractions (fraction $<2 \mu \mathrm{m}$ )

\begin{tabular}{lcc} 
Minerals (wt \%) & BE83 $^{(1)}$ & YK74 $^{(2)}$ \\
\hline Illite & 20 & 10 \\
Smectite & 20 & 63 \\
Illite/Smectite & 20 & 22 \\
Kaolinite & 35 & 2 \\
Others & 5 & 3 \\
\hline
\end{tabular}

4 (1): Deng et al. (2011a, 2011b, 2011c, 2012) and Nguyen (2013)

5 (2): Vandenberghe (2011)

6 
Table 3: Physical and index properties of Boom and Ypresian Clays

\begin{tabular}{|c|c|c|c|c|c|c|c|c|c|c|c|}
\hline Core & $\begin{array}{l}\text { Depth } \\
\text { (m) }\end{array}$ & $\begin{array}{l}\mathrm{G}_{\mathrm{s}} \\
(-)\end{array}$ & $\begin{array}{l}\mathrm{LL} \\
(-)\end{array}$ & $\begin{array}{l}\text { PL } \\
(-)\end{array}$ & $\begin{array}{l}\text { PI } \\
(-)\end{array}$ & $\begin{array}{c}\text { VBS } \\
(\mathrm{g} / 100 \mathrm{~g})\end{array}$ & $\begin{array}{c}\mathrm{CaCO}_{3} \\
(\% \mathrm{wt})\end{array}$ & $\begin{array}{l}e_{0} \\
(-)\end{array}$ & $\begin{array}{l}\mathrm{w}_{0} \\
(\%)\end{array}$ & $\begin{array}{l}\mathrm{S}_{\mathrm{r} 0} \\
(\%)\end{array}$ & $\begin{array}{c}\rho_{0} \\
\left(\mathrm{Mg} / \mathrm{m}^{3}\right)\end{array}$ \\
\hline $\mathrm{BE} 83^{(1)}$ & $\begin{array}{c}226.65- \\
227.65\end{array}$ & 2.64 & 67.2 & 32.5 & 34.7 & 6.7 & 0.76 & $\begin{array}{c}0.69- \\
0.72\end{array}$ & $\begin{array}{c}26.20- \\
28.13\end{array}$ & $\begin{array}{c}98.72- \\
100\end{array}$ & $\begin{array}{c}1.95- \\
1.97\end{array}$ \\
\hline YK74 & $\begin{array}{c}361.81- \\
362.60\end{array}$ & 2.80 & 136.6 & 36.1 & 100.5 & 13.1 & 0.88 & 0.84 & $\begin{array}{c}28.34- \\
28.52\end{array}$ & $\begin{array}{c}90.95- \\
95.27\end{array}$ & $\begin{array}{c}1.92- \\
1.96\end{array}$ \\
\hline
\end{tabular}

2 (1): Deng et al. (2011a, 2011b, 2011c, 2012) and Nguyen (2013).

$3 G_{s}$ : Specific gravity; LL: liquid limit; PL: plastic limit; PI: plasticity index, VBS: blue methylene value; $\mathrm{CaCO}_{3}$ :

4 carbonates content, $e_{0}$ : initial void ratio; $w_{0}$ : initial water content; $S_{r 0}$ : initial degree of saturation; $\rho_{0}$ : initial 5 density.

6

Table 4: Pore-water chemical compositions for Boom and Ypresian Clays

\begin{tabular}{l|cc|cc}
\multirow{2}{*}{ Salts } & \multicolumn{2}{|c|}{ Concentration $\left(10^{-3} \mathrm{M}\right)$} & \multicolumn{2}{c}{ Concentration (g/L) } \\
& BE83 & YK74 $^{(1)}$ & BE83 $^{(1)}$ & YK74 \\
\hline $\mathrm{NaCl}$ & 54.6 & 117.9 & 3.195 & 6.896 \\
$\mathrm{Na}_{2} \mathrm{SO}_{4}$ & 5.2 & 6.3 & 0.742 & 0.896 \\
$\mathrm{NaHCO}_{3}$ & 7.2 & & 0.602 & \\
$\mathrm{KCl}$ & 0.6 & & 0.046 & \\
$\mathrm{CaCl}_{2}$ & 0.5 & & 0.058 & \\
$\mathrm{MgCl}_{2}$ & 1.4 & & 0.137 & \\
\hline Salinity & & & 4.78 & 7.79 \\
\hline Total Na+ & 72.2 & 130.5 & & \\
\hline
\end{tabular}

8 (1): De Craen et al. (2006)

9 (2): van Marcke (2009)

10 
Table 5: Test program

\begin{tabular}{llcccc} 
Soils & Test ID & $\begin{array}{c}\text { Solution } \\
\text { soaked }\end{array}$ & $\begin{array}{c}\text { Solution } \\
\text { injected at 1 MPa }\end{array}$ & $\begin{array}{c}\mathrm{e}_{0} \\
(-)\end{array}$ & $\begin{array}{c}\mathrm{S}_{\mathrm{r} 0} \\
(\%)\end{array}$ \\
\hline \multirow{3}{*}{ Boom } & $\mathrm{BO}^{(1)}$ & $\mathrm{SBCW}$ & $\mathrm{H} 2 \mathrm{O}$ & 0.730 & - \\
Clay & $\mathrm{BO}^{(1)}$ & $\mathrm{SBCW}$ & $\mathrm{SBCW}$ & 0.730 & - \\
& $\mathrm{BO} 3$ & $\mathrm{SBCW}$ & $\mathrm{NaCl} \mathrm{15} \mathrm{g} / \mathrm{L}$ & 0.720 & 99.09 \\
& $\mathrm{BO} 4$ & $\mathrm{SBCW}$ & $\mathrm{NaCl} \mathrm{30} \mathrm{g/L}$ & 0.723 & 98.72 \\
\hline Ypresian & $\mathrm{YO} 1$ & $\mathrm{SYCW}^{(2)}$ & $\mathrm{NaCl} \mathrm{15} \mathrm{g} / \mathrm{L}$ & 0.840 & 94.57 \\
Clays & $\mathrm{YO} 2$ & $\mathrm{SYCW}$ & $\mathrm{NaCl} \mathrm{30} \mathrm{g/L}$ & 0.839 & 95.27 \\
\hline
\end{tabular}

3 (1): Deng et al. (2011a) and Nguyen (2013)

4 (2): Synthetic Ypresian Clay Water

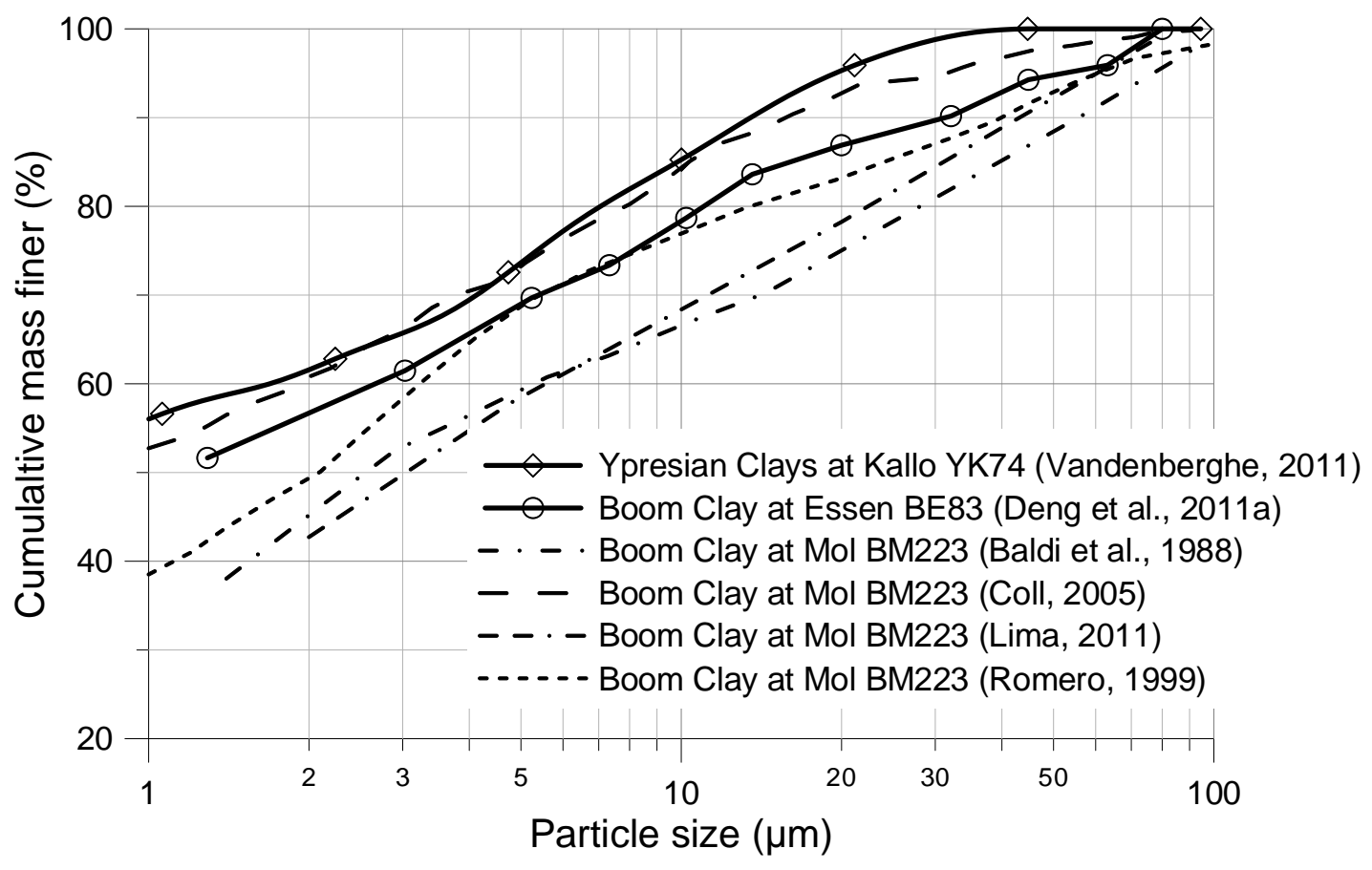

Figure 1: Particle-size distribution curves of Boom and Ypresian Clays 

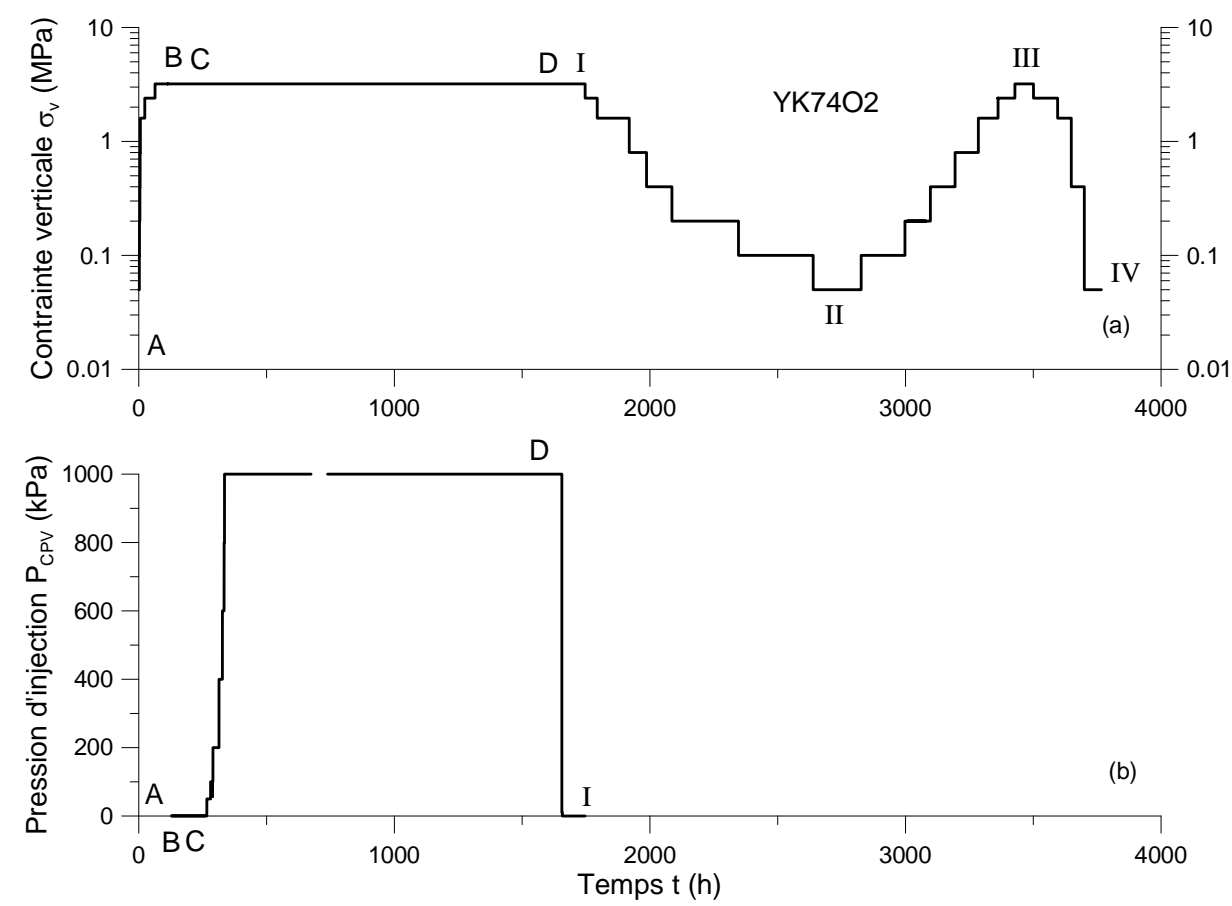

Figure 2: Typical loading procedure

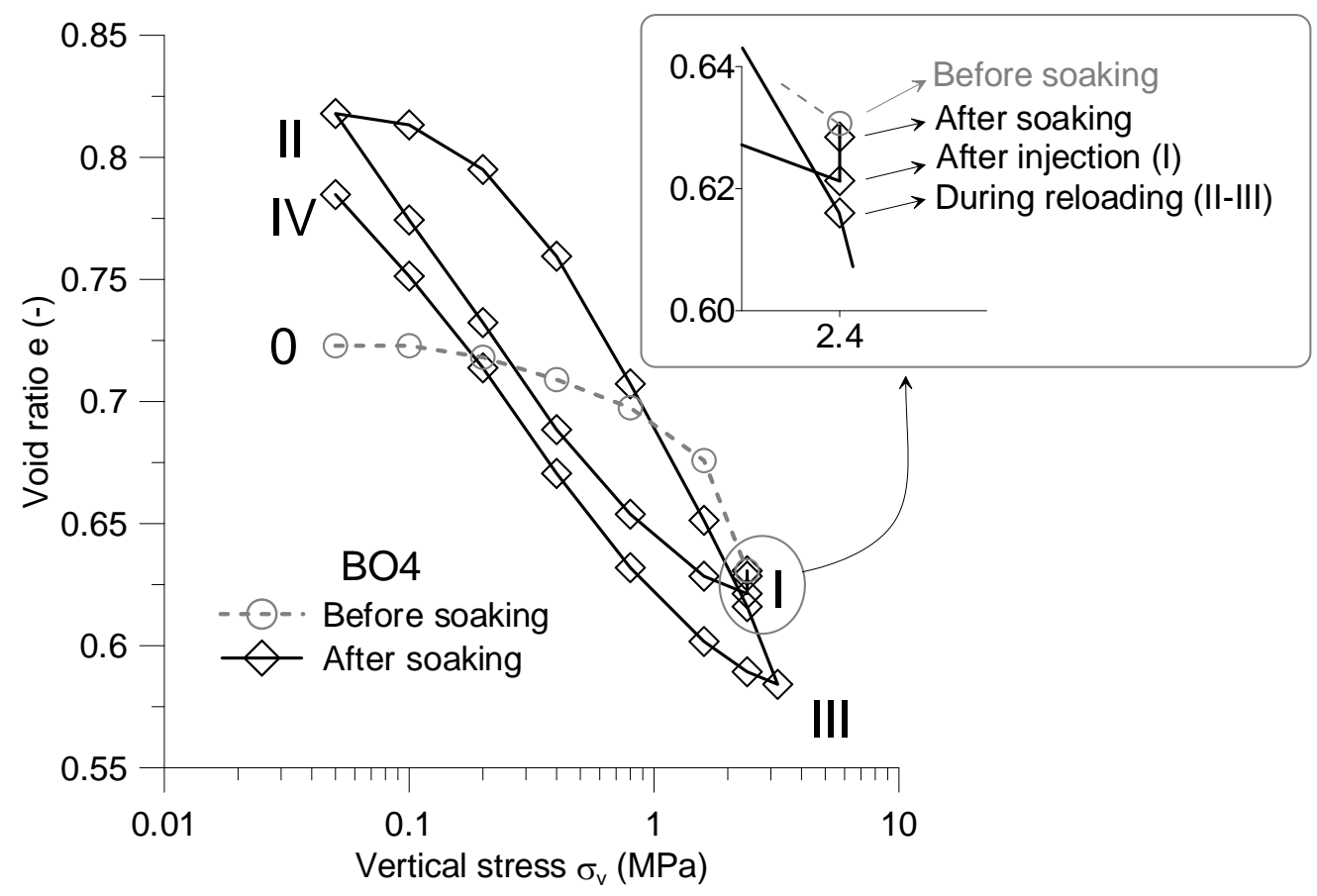




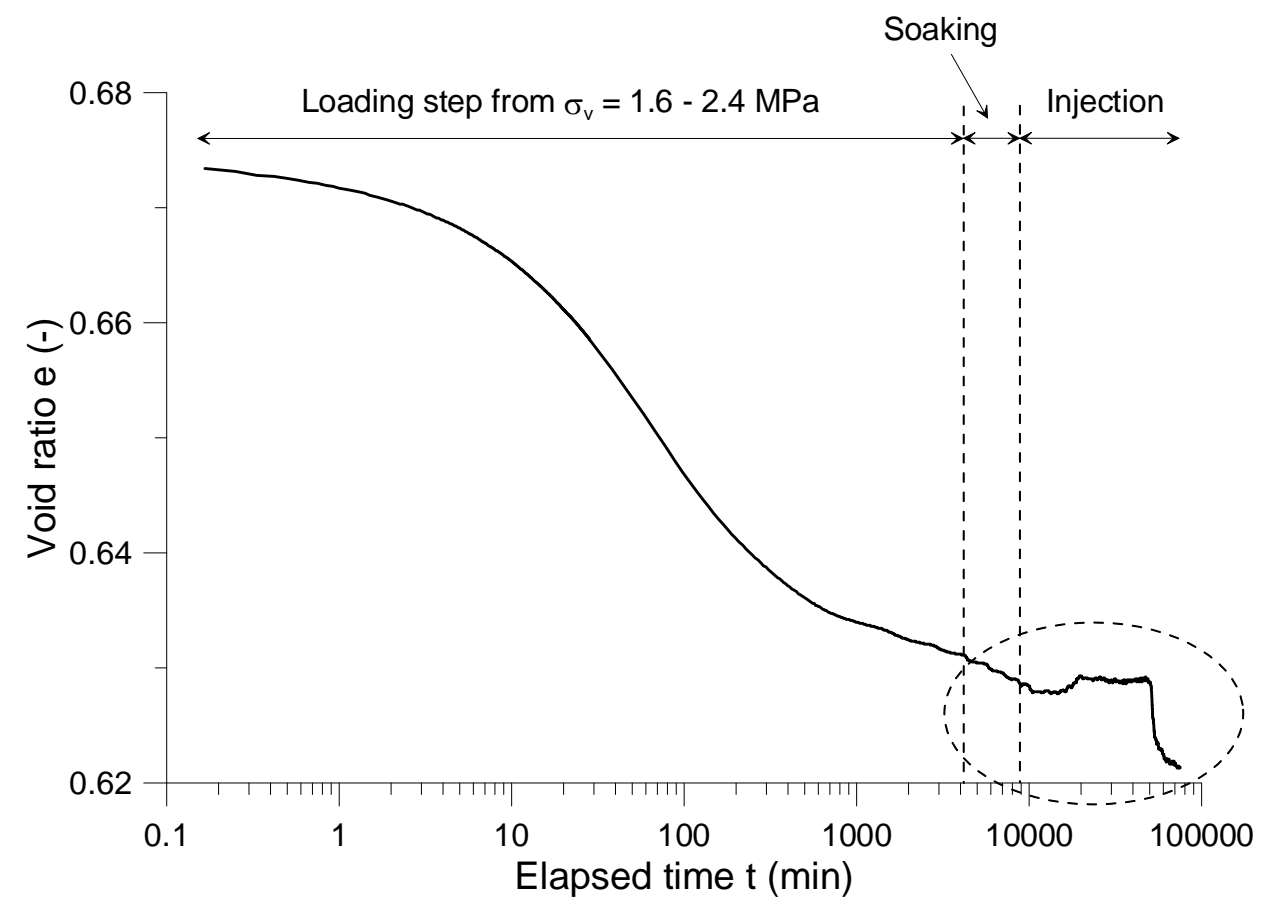

Figure 4: Consolidation curve for the last loading step before soaking, soaking and injection of $\mathrm{NaCl}$ solution at $30 \mathrm{~g} / \mathrm{L}$-concentration in test $\mathrm{BO} 4$ (Boom Clay)

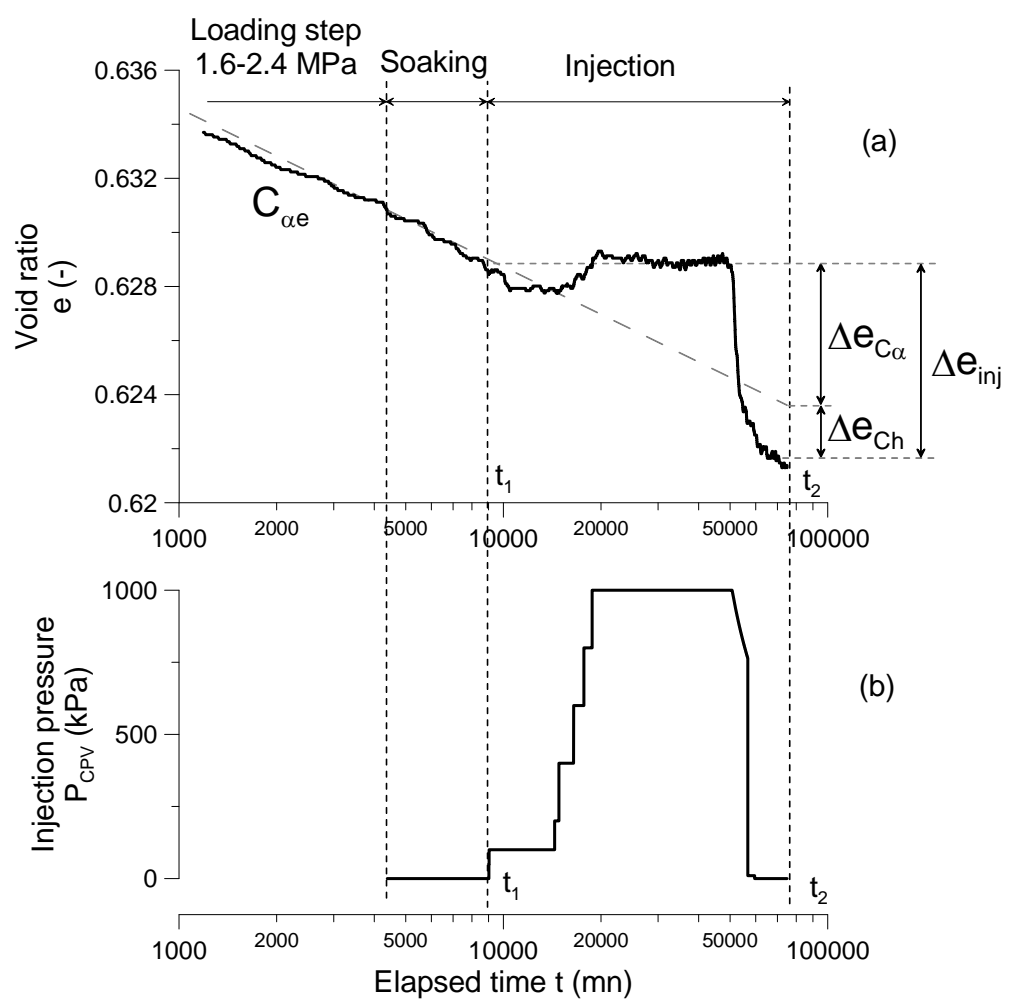

5 Figure 5: Void ratio (a) and injection pressure (b) changes during the injection phase in test BO4 (Boom 


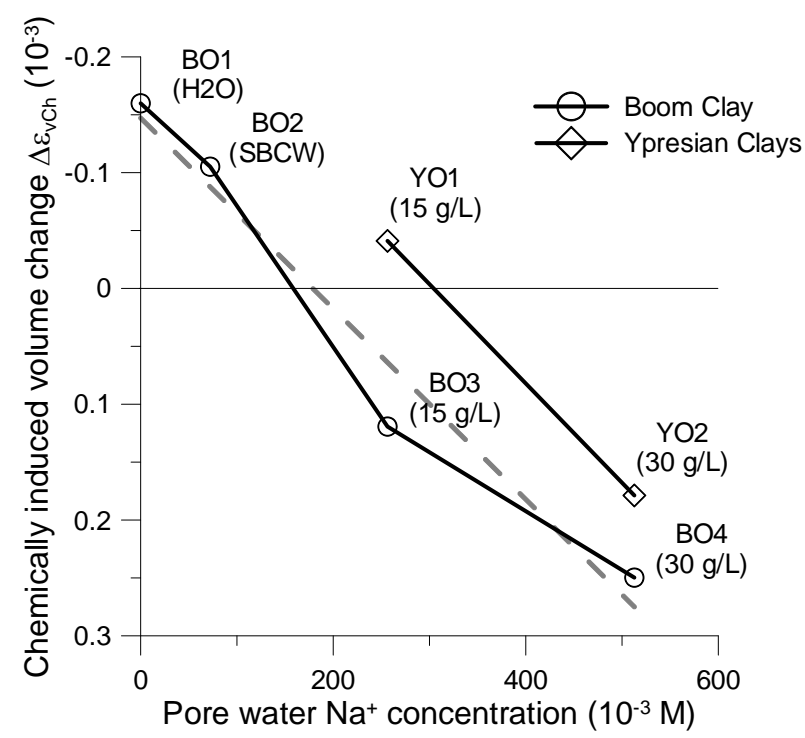

3 Figure 6: Chemically induced volume change versus pore water $\mathrm{Na}^{+}$concentration during solution injection 4

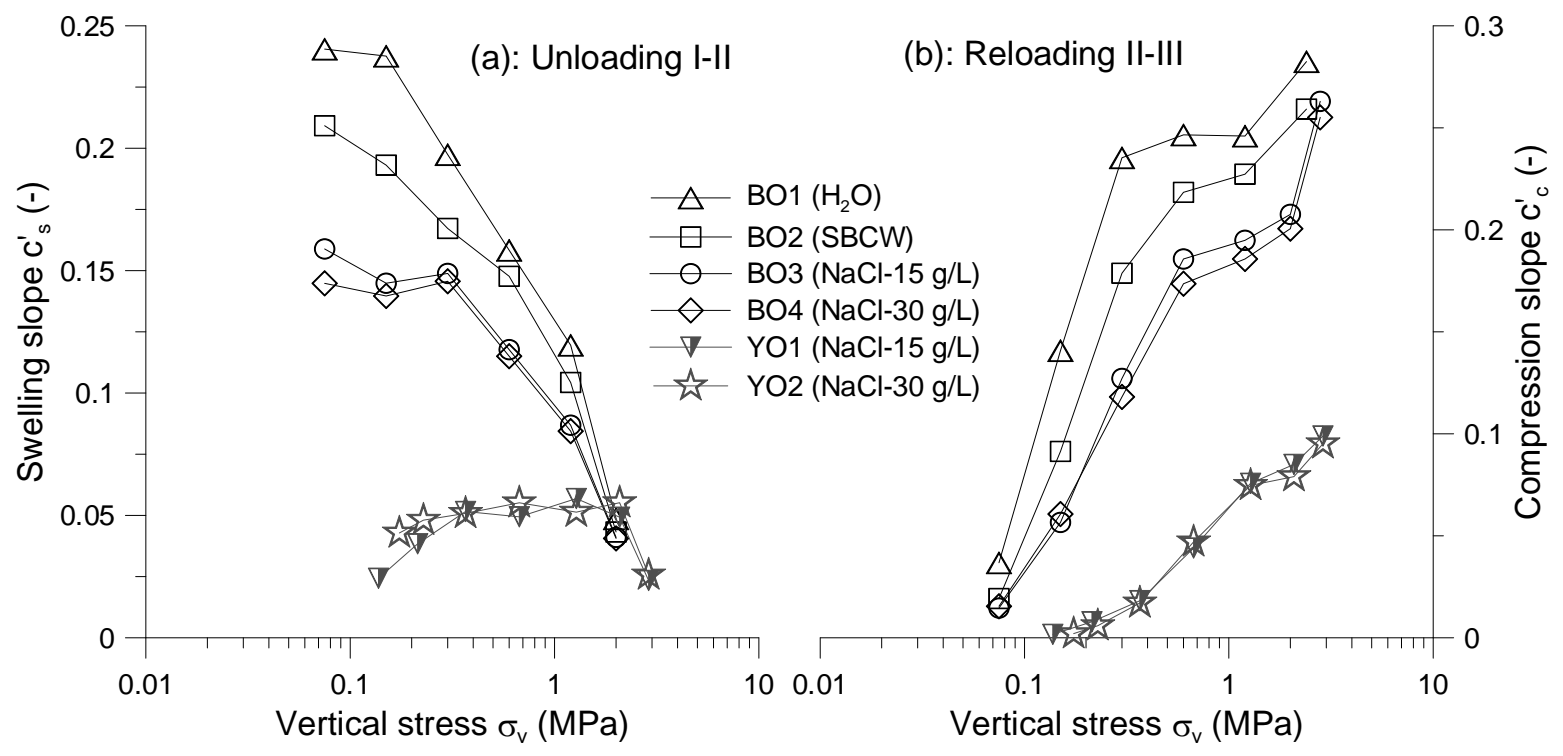




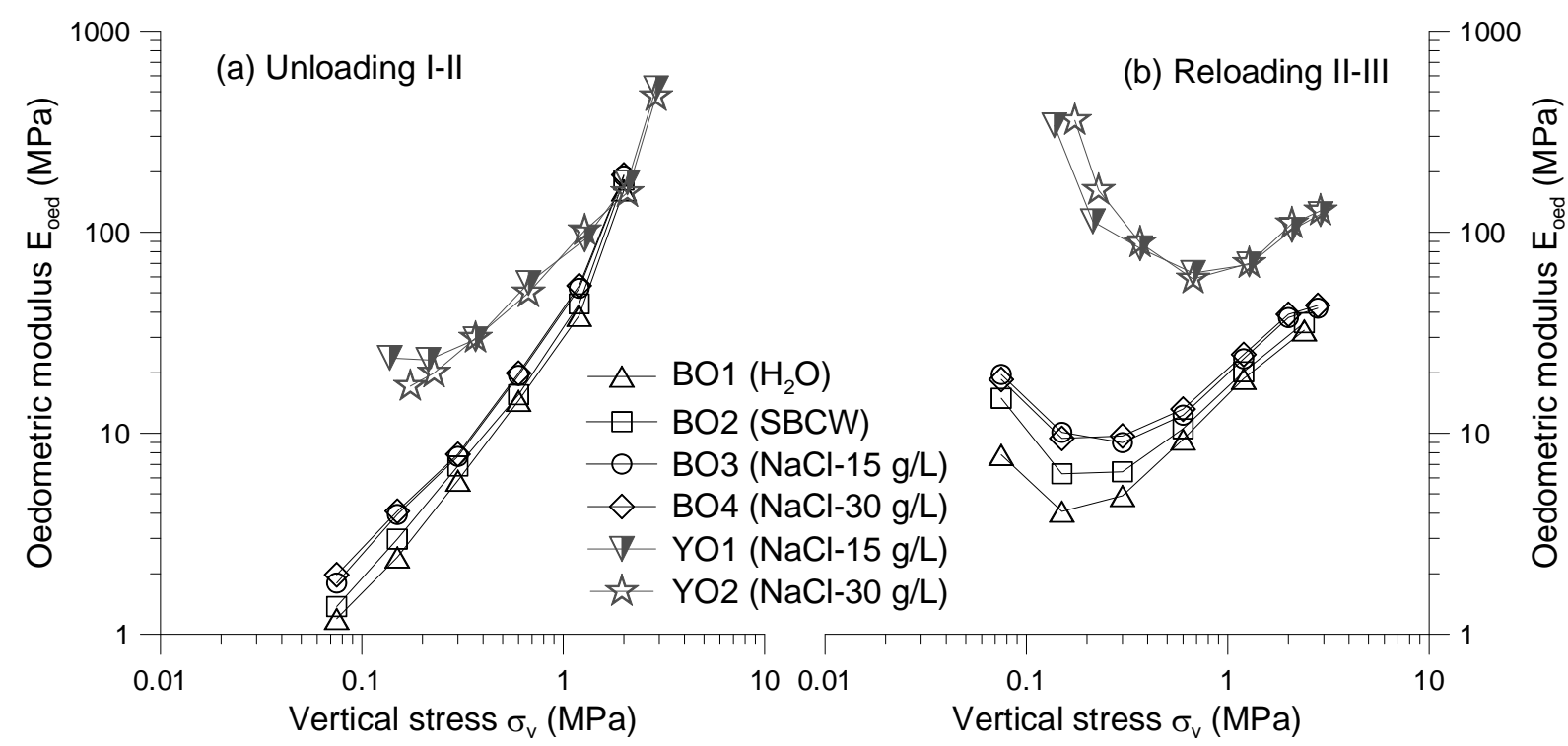

2 Figure 8: Variations of œedometric modulus with vertical stress during unloading I-II (a) and reloading II-III

(b)

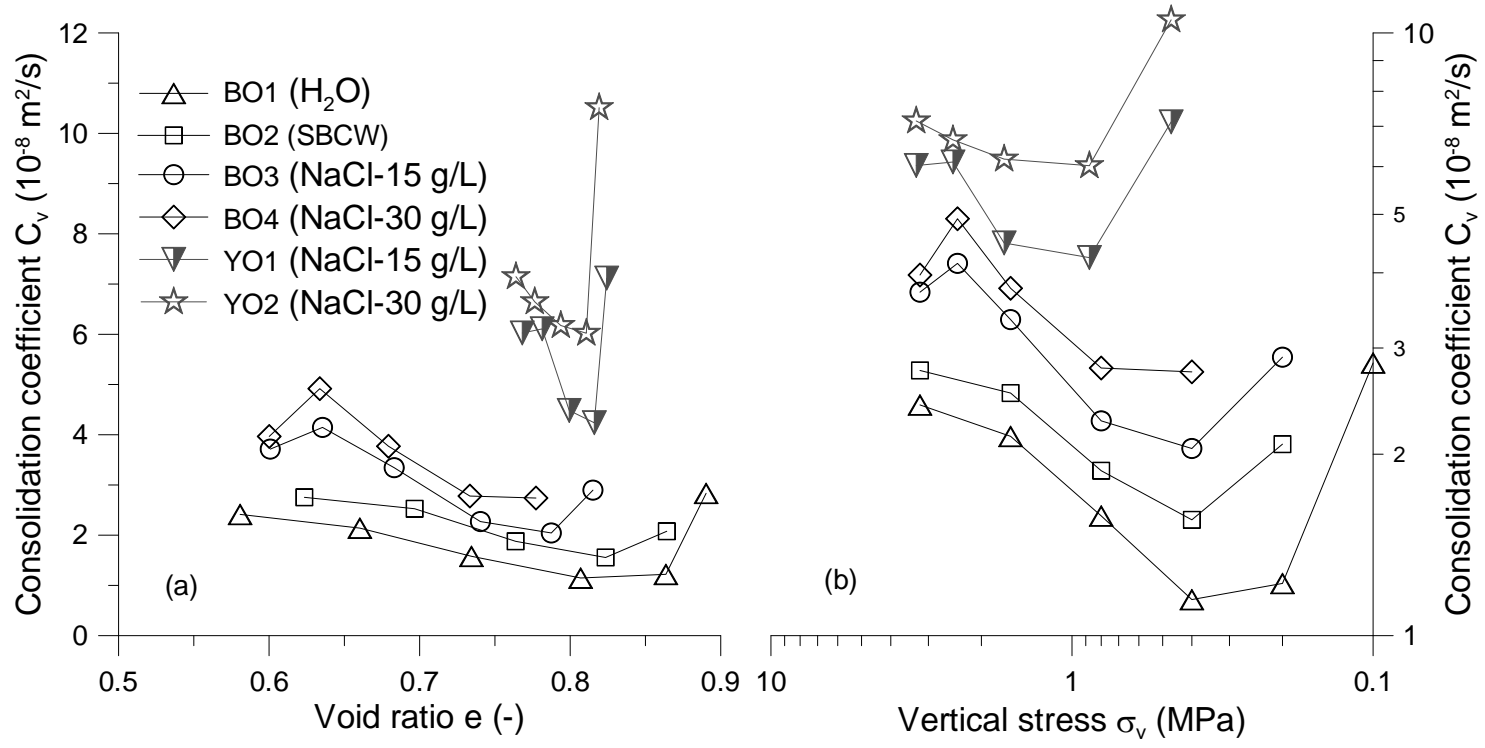

5 Figure 9: Variations of consolidation coefficient with a) void ratio and b) vertical stress during reloading 


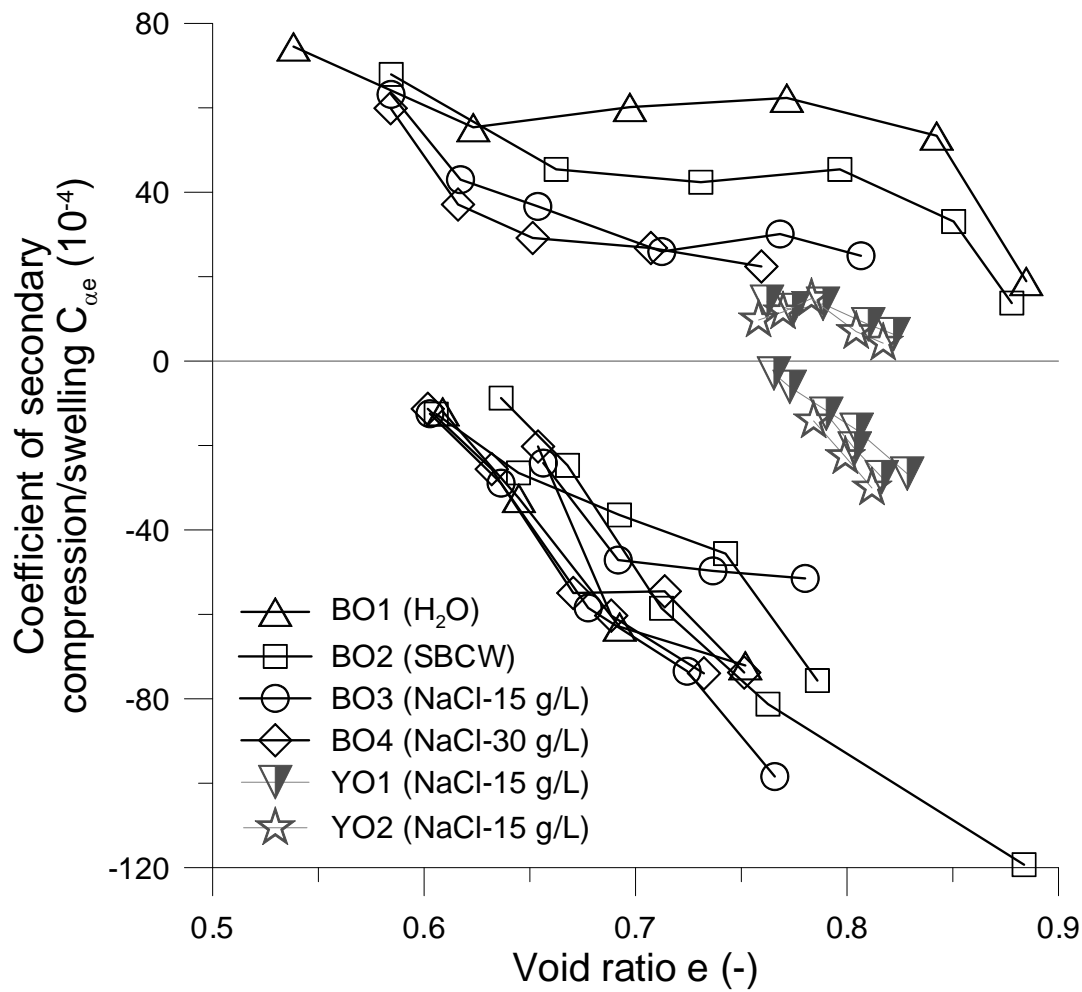

2 Figure 10: Variations of secondary compression/swelling coefficient with void ratio for Boom Clay and Ypresian Clays

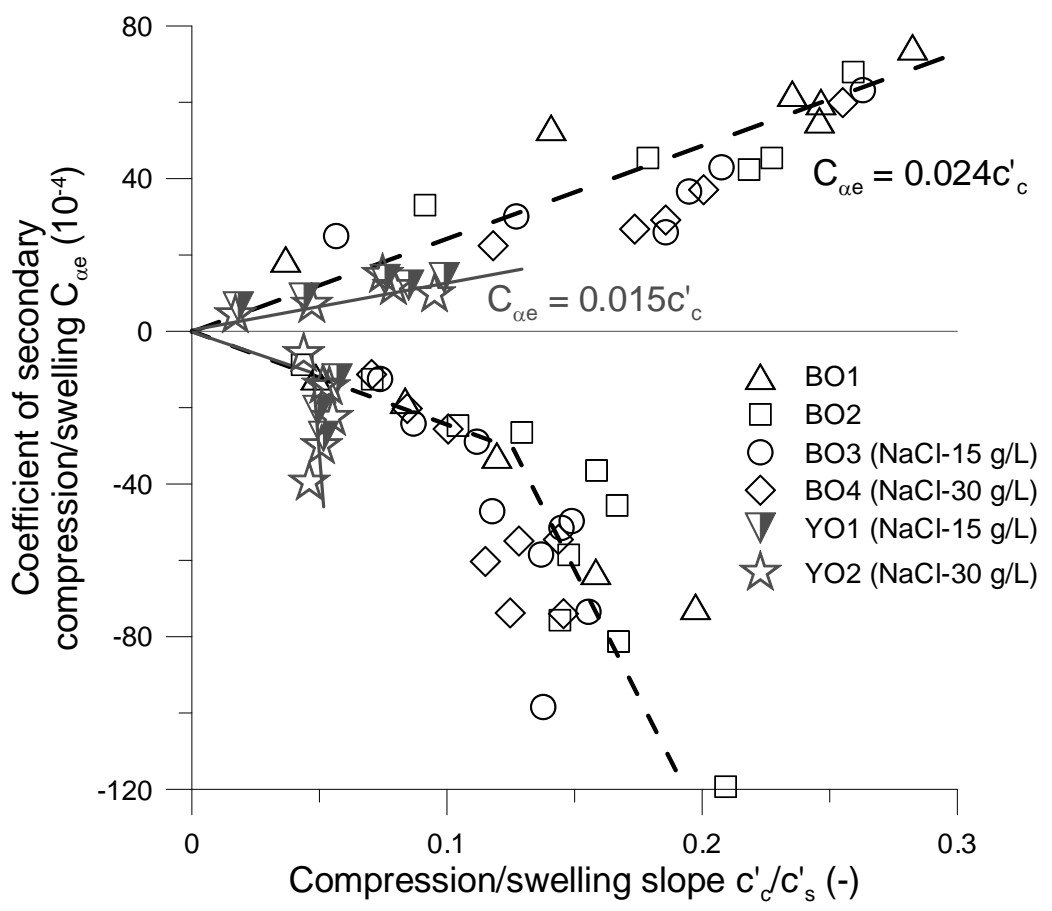

Figure 11: Correlations between $C_{\alpha e}$ and $c_{c}{ }_{c}$ or $c$ ', for Boom Clay and Ypresian Clays 


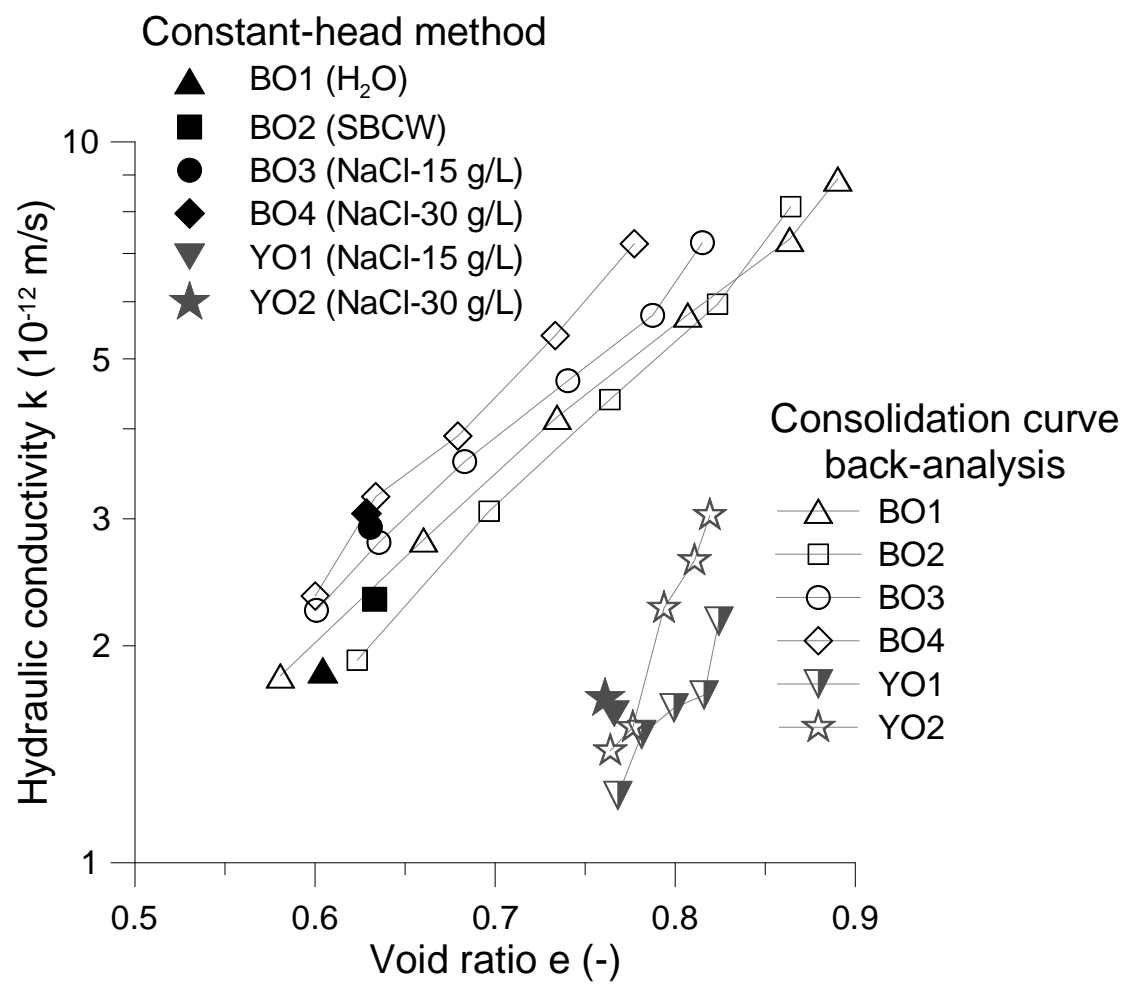

Figure 12: Variations of intrinsic permeability with void ratio 

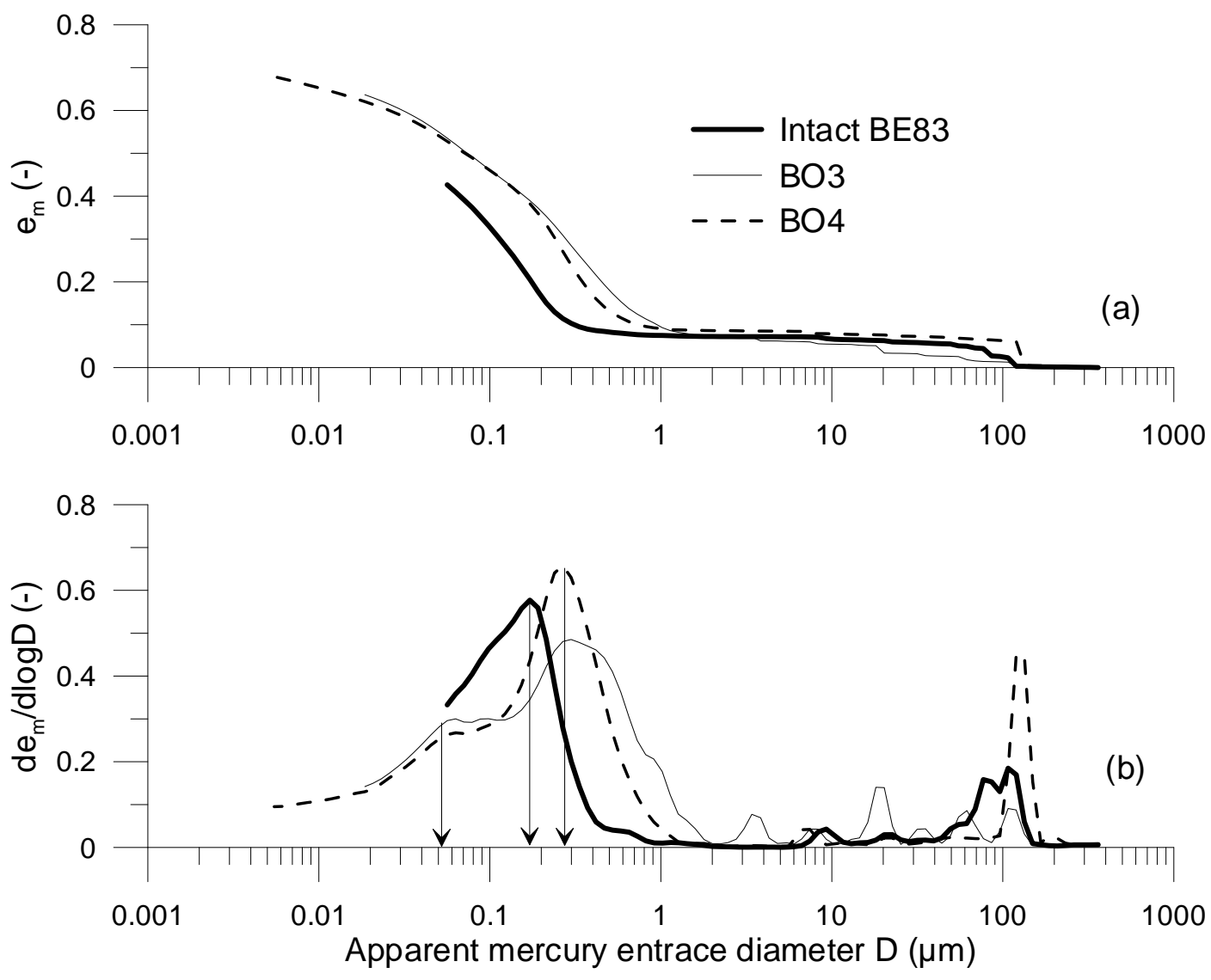

Figure 13: Results of MIP tests on Boom Clay: (a) cumulative curves, (b) derived curves 

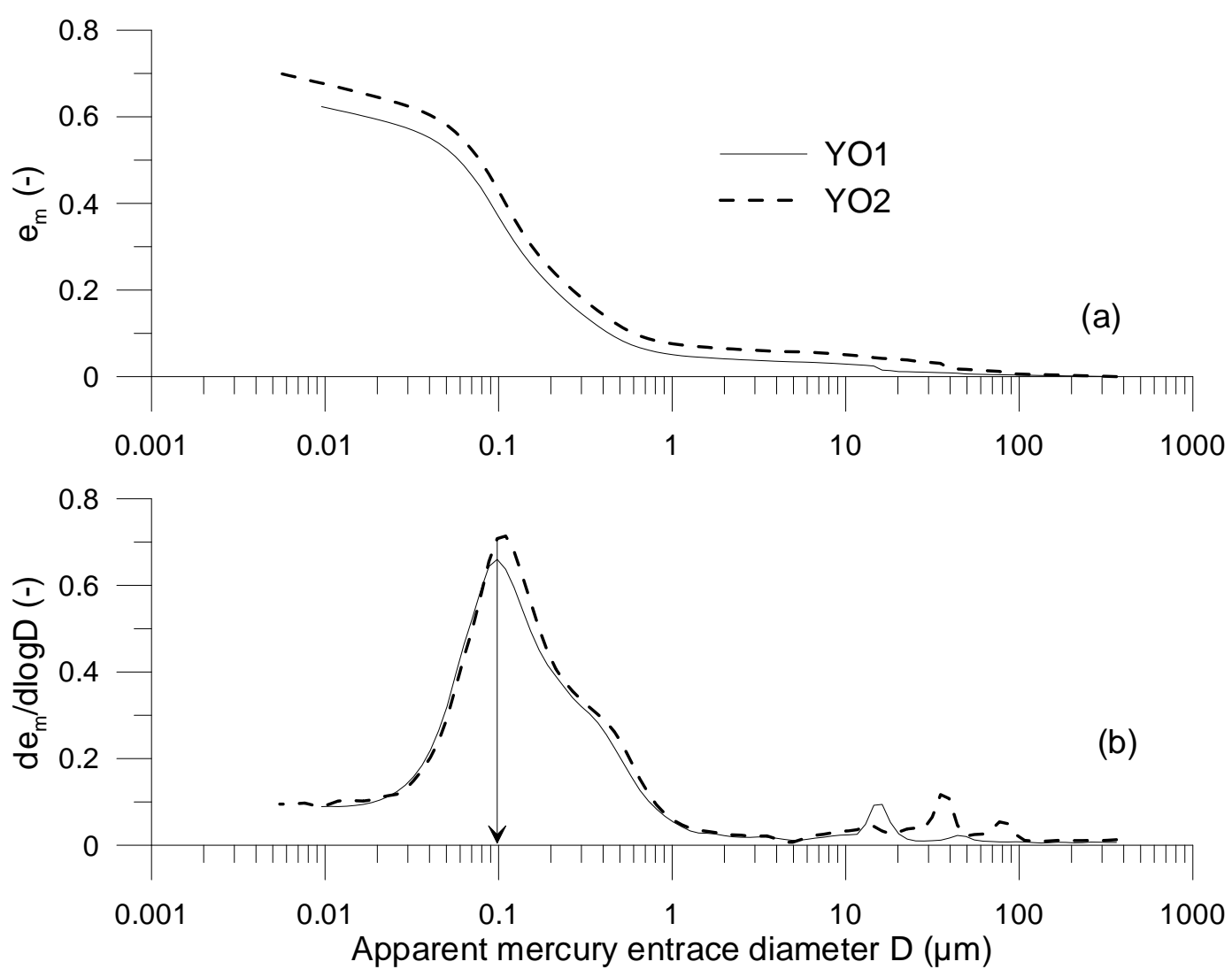

Figure 14: Results of MIP tests on Ypresian Clays: (a) cumulative curves, (b) derived curves 


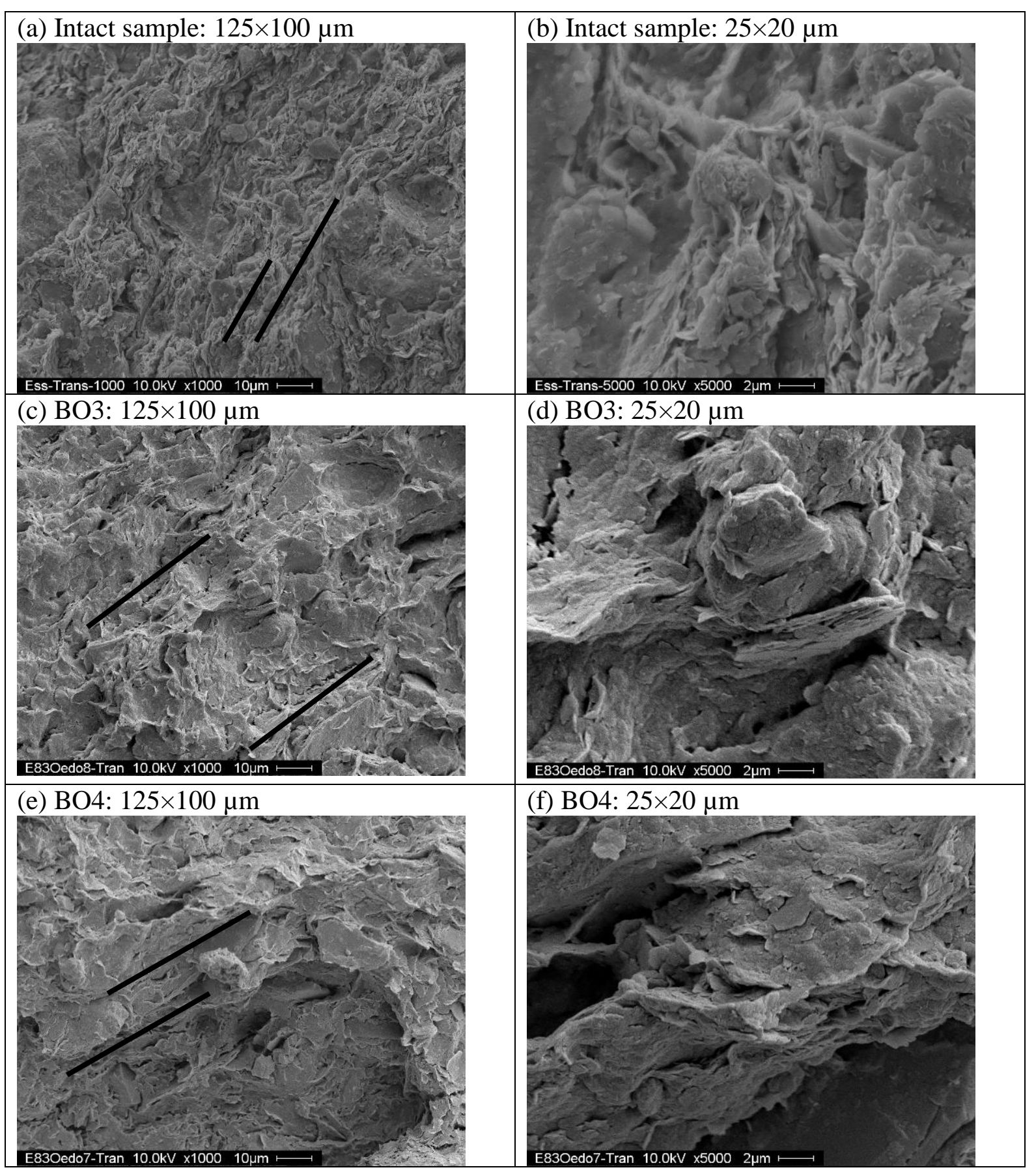

Figure 15: SEM photos of Boom Clay samples on the section perpendicular to bedding plane (marked by black lines) 


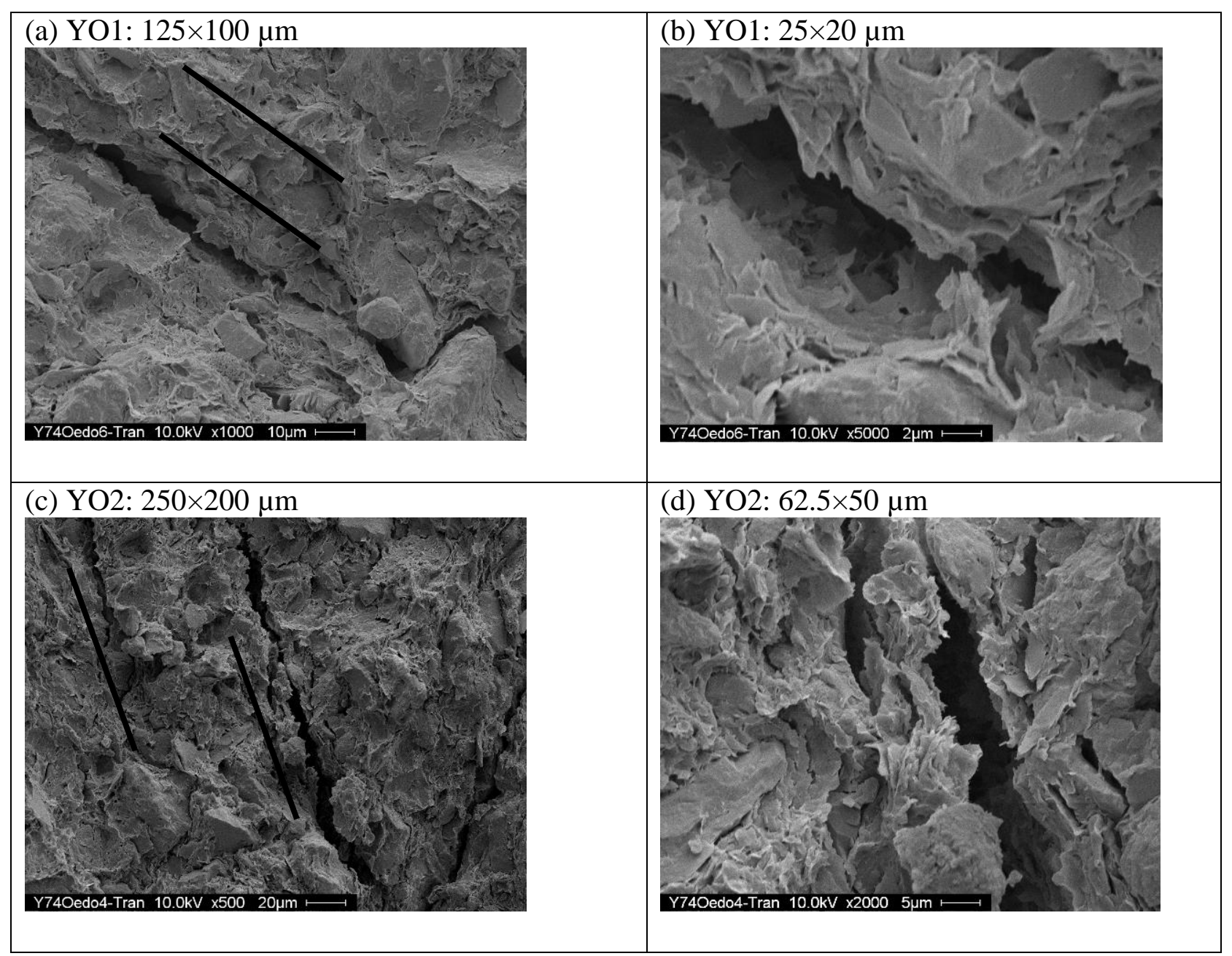

Figure 16: SEM images of Ypresian Clays samples on the section perpendicular to the bedding plane (marked by black lines) 


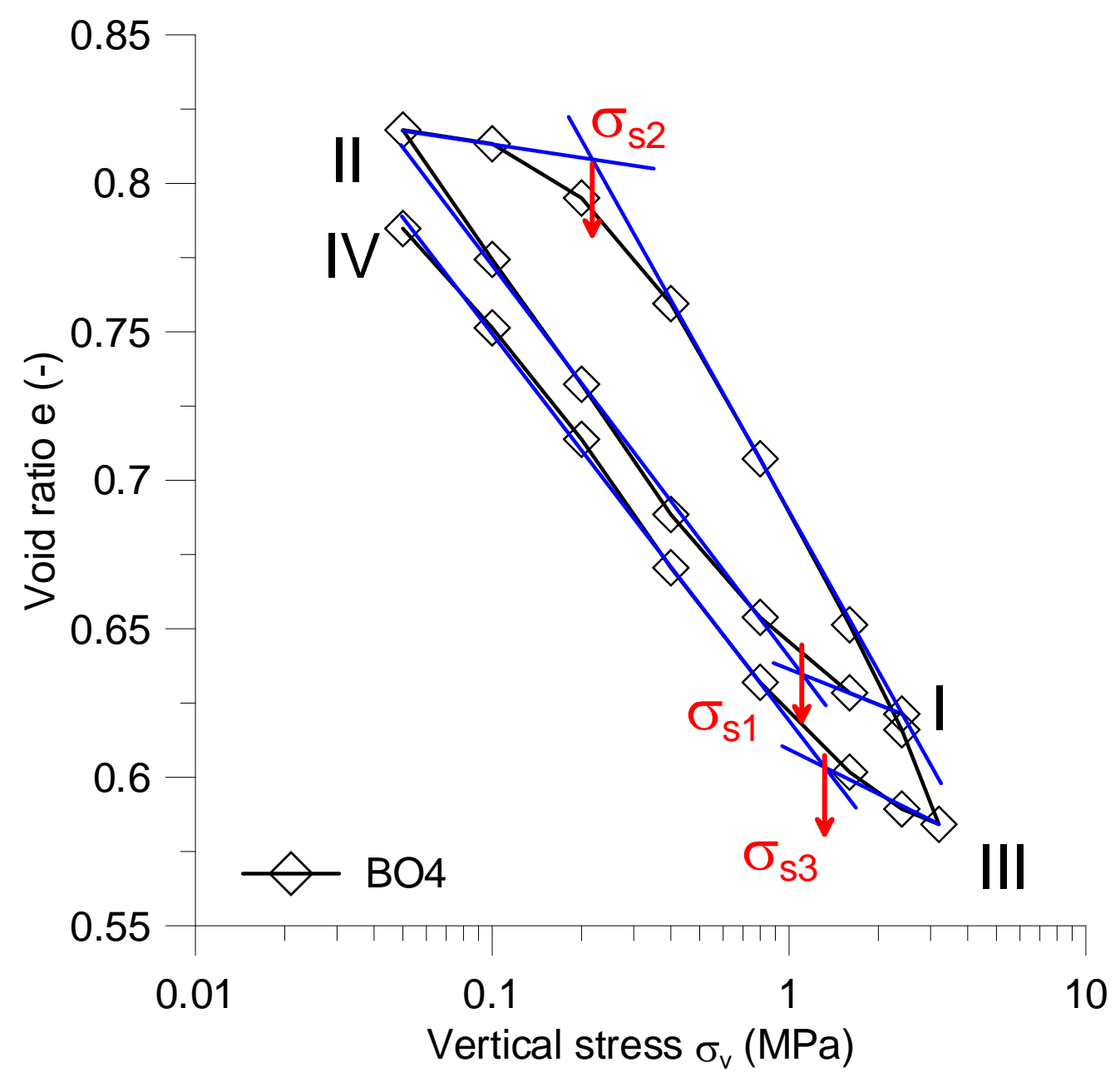

Figure 17: Threshold stress $\sigma_{s}$ 